Two reduced kinetic models, incorporating thermal, $\mathrm{N}_{2} \mathrm{O}, \mathrm{NNH}$ as well as $\mathrm{HNO} / \mathrm{NO}_{2}$ intermediate routes, are proposed for the quick evaluation of NO emissions from MILD combustion of $\mathrm{H}_{2}$-enriched fuels through post-processing of Computational Fluid Dynamics simulations. The models were derived from a Rate Of Production Analysis carried out with two different detailed kinetic schemes. The models were tested using data from the Adelaide Jet in Hot Coflow burner fed with $\mathrm{CH}_{4} / \mathrm{H}_{2}$ mixture and operated with three different $\mathrm{O}_{2}$ contents. Very satisfactory predictions of in-flame NO measurements were achieved for the three cases, indicating a good applicability of the models across a wide range of MILD combustion conditions. Significant impact of the NNH intermediate path was observed.

7 Keywords: flameless combustion; NNH; Computational Fluid Dynamics;

8 turbulence-chemistry interaction; hydrogen

9 1. Introduction

\section{Reduced NO formation models for CFD simulations of MILD combustion}

\author{
Chiara Galletti ${ }^{\mathrm{a}, *}$, Marco Ferrarotti ${ }^{\mathrm{a}}$, Alessandro Parente $^{\mathrm{b}, *}$, Leonardo Tognotti $^{\mathrm{a}}$ \\ ${ }^{a}$ Dipartimento di Ingegneria Civile e Industriale - Universitá di Pisa \\ ${ }^{b}$ Service d Áero-Thermo-Mécanique, Université Libre de Bruxelles, Bruxelles, Belgium
}

\begin{abstract}
MILD (Moderate or Intense Low-Oxygen Combustion) combustion, also known as flameless combustion is able to provide high combustion efficiency with low $\mathrm{NO}_{x}$ and soot emissions [1]. The technology needs the reactants to be preheated above their self-ignition temperature and enough inert combustion products to be entrained in the reaction region, in order to dilute both reactants and flame. The system is characterized by a more uniform temperature field than in traditional non-premixed combustion, and by the absence of high temperature peaks, thus suppressing NO formation through the thermal mechanism. The technology shows common features with High Temperature Air Combustion (HiTAC) due to the common practice of preheating the oxidizer. MILD combustion is very stable and noiseless, so it is potentially suited for gas turbine applications. Recently it has also been
\end{abstract}

${ }^{*}$ Corresponding authors. Dr. Chiara Galletti, email:chiara.galletti@ing.unipi.it. Dr. Alessandro Parente, Briegrin January 28, 2015 
suggested for oxy-fuel combustion, a technology able to provide a step-wise reduction of greenhouse gases emissions through the $\mathrm{CO}_{2}$ capture and storage (CCS). However what makes such technology very attractive is the large fuel flexibility, being suited for low-BTU fuels [2], industrial wastes [3], biogas [4] [5] as well as in presence of hydrogen.

$\mathrm{H}_{2}$-enriched fuels have received attention as they may be obtained from the gasification of solid fuels, including biomasses; moreover $\mathrm{H}_{2}$-enriched mixtures represent sometimes byproducts of industrial processes [3]. However, hydrogen shows some specific properties (high laminar flame speed, high adiabatic flame temperature and heating value, large flammability range, high reactivity and short delay time) which make conventional burners unsuited: diffusive burners produce too large NOx emissions because of the very high temperatures, whereas premixed flames burners could suffer of stability problems and flashback phenomena. As a matter of fact, the use of MILD combustion technology appears particularly beneficial for controlling $\mathrm{NO}_{x}$ formation, providing a manner to limit the reactivity of hydrogen-based fuels [6] [7] [8] [9] [10].

The design of novel combustion technologies has taken advantages of recent progresses in Computational Fluid Dynamics (CFD) tools, offering considerable time and cost savings with respect to experimental campaigns as well as the possibility to be applied directly to the scale of interest. Turbulent combustion modelling of practical systems involves often heavy computational grids to describe burners, gas turbines, furnace/boilers, etc., so that Favre-averaged Navier-Stokes (FANS) equations are usually formulated to make the calculations affordable even with parallel computing. In this framework, different sub-models (e.g. turbulence model, combustion model/kinetic scheme) are needed for closure; such models have been derived for conventional combustion and need to be validated/revised for novel technologies. Hence, many efforts have been done in recent years to improve CFD predictivity for MILD combustion systems by validating/revising the different sub-models.

Logically, this issue requires high fidelity and comprehensive experimental data to validate the numerical models. The Adelaide Jet in Hot Coflow (JHC) burner [11] [12] [13] [14] and the Delft Jet in Hot Coflow (DJHC) burner [15] [16] [17] have been developed on purpose to emulate MILD combustion conditions by feeding diluted and hot streams, and constitute a strong asset for the validation of numerical models as they have been equipped with advanced diagnostics to measure mean and fluctuating variables (e.g. chemical species, temperature, velocities). As a matter of fact, they have been objective of numerous mod- 
elling works, especially aimed at validating the turbulence/chemistry interaction treatment and kinetic schemes (e.g. [18] [19] [20] [21] [22] [23] [24] [25] [26]), as well as the use of more complex modelling approaches based on Large Eddy Simulations (e.g.[27] [28] [29]).

Recently a novel methodology to evaluate the chemical time-scale in case of complex kinetic schemes was proposed and applied to JHC experimental data, indicating that the Damköhler number, which is given by the mixing to chemical time-scale ratio, approaches unity, i.e. $D a=\tau_{m} / \tau_{c} \approx 1$ [30]. This implies a strong coupling between mixing and chemical kinetics resulting in a very challenging problem. Indeed, many investigators observed satisfactory performance of the Eddy Dissipation Concept (EDC) [31] [32] to treat the turbulence/chemistry interaction in MILD combustion conditions, especially for its capability to incorporate efficiently detailed kinetic schemes [18] [26] [24] [20] [23]; however modifications of the EDC model have been suggested to improve prediction for both JHC [22] and DJHC [25] flames.

Actually, little attention has been paid to the modelling of $\mathrm{NO}_{x}$ emission, even though they constitute a main concern when addressing novel combustion technologies and especially MILD combustion.

From the modelling perspective, the description of NO formation in MILD combustion, requires the incorporation of additional mechanisms, beside the ones typically adopted for conventional combustion systems, i.e. thermal and prompt. The low-temperature operation of MILD combustion systems inhibits $\mathrm{NO}_{x}$ formation via the thermal-NO mechanism with respect to conventional combustion [33] [34] and increases the importance of alternative formation routes, such as the Fenimores prompt $\mathrm{NO}[35]$ and/or $\mathrm{N}_{2} \mathrm{O}$ intermediate mechanisms. Prompt NO are formed by the reaction of atmospheric nitrogen with hydrocarbon radicals with the consecutive oxidation of the intermediate species to NO. This mechanism becomes significant in particular combustion environments, such as in low-temperature, fuel rich conditions and short residence time. Malte and Pratt [36] proposed the first NO formation mechanism via the intermediate specie $\mathrm{N}_{2} \mathrm{O}$. This mechanism, under favorable conditions such as elevated pressure, temperature below $1800 \mathrm{~K}$ and oxygen-rich conditions, can contribute as much as $90 \%$ of the total NO. Therefore this makes it particularly important in gas turbines and compression-ignition engines. Nicolle and Dagaut [37] investigated numerically MILD combustion of $\mathrm{CH}_{4}$ in perfecly stirred and plug flow reactors, i.e. PSRs and PFRs) and showed that the $\mathrm{N}_{2} \mathrm{O}$ pathway is fundamental in the post-ignition period . 
In presence of hydrogen, the NNH intermediate route [38] could be also important. Galletti et al. [6] evaluated NO emissions in a lab-scale burner operating in MILD combustion conditions and fed with $\mathrm{CH}_{4} / \mathrm{H}_{2}$ mixture and compared them to flue gas measurements, finding that the $\mathrm{NNH}$ intermediate and $\mathrm{N}_{2} \mathrm{O}$ were the main formation routes. The same conclusion was drawn by Parente et al. [39] who evaluated NO emissions from a self-recuperative industrial burner fed with $\mathrm{CH}_{4} / \mathrm{H}_{2}$ mixture with different $\mathrm{H}_{2}$ content. Although results were satisfactory, the use of only flue gas measurements prevented from an accurate validation of the NO formation models, which were based on simple reaction schemes from literature.

The JHC measurements [11] again may provide a strong asset for the validation and development of NO formation models to be used for MILD combustion systems, because of the availability of in-flame NO experimental data. Kim et al. [19] employed the Conditional Moment Closure (CMC) method, by using a laminar flamelet model together with a presumed $\beta$-PDF for single mixture fraction to model the JHC. They evaluated NO emissions through thermal and prompt mechanisms but found some discrepancies, which they attributed to the poor performance of the overall model in predicting the mixing. Frassoldati et al. [23] applied a detailed Kinetic Post Processor to CFD simulations of $\mathrm{CH}_{4} / \mathrm{H}_{2}$ flames in the JHC, in order to compute $\mathrm{NO}_{x}$ emissions. They observed a satisfactory overall agreement with experimental measurements, even though there were discrepancies between measured and predicted NO profiles downstream (i.e. at axial distances of $120 \mathrm{~mm}$ ) which they attributed to the overestimation of the temperature field of $\approx 100 \mathrm{~K}$, as well as near the flame axis. Importantly, they observed that in the near burner region, NO is formed through mainly $\mathrm{NNH}$ and $\mathrm{N}_{2} \mathrm{O}$ mechanisms, whereas the prompt $\mathrm{NO}$ formation takes place further away.

The present paper aims at validating some simple existing NO formation schemes to be used for the practical simulations of MILD combustion systems as well as at developing new schemes suited for MILD conditions, also in presence of hydrogen. Attention is paid to computationally-affordable models as the idea is to use them for quick post-processing calculations of CFD results to be employed for the design of practical systems.

The JHC burner fed with $\mathrm{CH}_{4} / \mathrm{H}_{2}$ mixture [11] is used as reference case. The first step is a good prediction of the thermochemical field in order to limit errors in NO calculations related to non-accurate temperature and species field. Hence, new comprehensive models for $\mathrm{NO}_{x}$ formation in MILD combustion conditions are developed on the basis of Rate Of Production Analysis performed in a perfectly stirred reactor with detailed kinetics schemes. 
The performance of these model in predicting $\mathrm{NO}_{x}$ emissions is compared to existing simple models as well as to the comprehensive model proposed by Löffler et al. [40].

Gao et al. [41] carried out simulations of the JHC to investigate the mechanisms of NO formation in MILD combustion. NO production was accounted by including NO formation routes in the kinetic mechanism, i.e. GRI2.11, handled by the Eddy Dissipation Concept for turbulence/chemistry interactions. Such a modelling choice may be justified for MILD conditions, given the reduced importance of the thermal formation route, and the relevance of non conventional pathways, i.e. NNH, with characteristic formation times inherently coupled to the gas-phase chemistry. However, numerical results showed discrepancies with respect to experiments, likely to be attributed to the overestimation of the temperature field due to the non-optimal choice of the EDC constants (see discussion above).

\section{Test case}

The Adelaide Jet in Hot Coflow burner modelled in this work has been experimentally studied by Dally et al. [11] and it is shown for sake of clarity in Figure 1a. It consists of a fuel jet nozzle, which has an inner diameter of $4.25 \mathrm{~mm}$ and a wall thickness of 0.2 $\mathrm{mm}$, located at the centre of a perforated disc in an annulus, with inner diameter of $82 \mathrm{~mm}$ and wall thickness of $2.8 \mathrm{~mm}$, which provides nearly uniform composition of hot oxidizer coflow to the reaction zone. The entire burner was placed inside a wind tunnel introducing room temperature air at the same velocity as the hot coflow. Table 1 shows the operating conditions of three inlet streams for the different case studies. The notations, HM1, HM2 and HM3, refer to the flames with oxygen mass fraction of $3 \%, 6 \%$, and $9 \%$, respectively, in the hot coflow stream. The jet Reynolds number was around 10,000 for all flames. The available data consist of the mean and root mean square (rms) of temperature and concentration of major $\left(\mathrm{CH}_{4}, \mathrm{H}_{2}, \mathrm{H}_{2} \mathrm{O}, \mathrm{CO}_{2}, \mathrm{~N}_{2}\right.$ and $\left.\mathrm{O}_{2}\right)$ and minor species (NO, CO and $\left.\mathrm{OH}\right)$. More details can be found in Dally et al. [11]. As for NO emissions, these are expected to increase when moving from HM1 to HM3 flames. HM1 flame better emulates MILD combustion conditions with very diluted concentration of $\mathrm{O}_{2}$, so it provides the lowest $\mathrm{NO}$ emissions.

\section{Numerical model}

The numerical model of the burner is mainly based on previous works [26] [22], so only a brief description will be given here. The geometry of the JHC flames allowed to use 
a 2D axisymmetric domain, constructed starting from the burner exit (Figure 1b). The computational grid was structured with $73 \times 340(24 \mathrm{k})$, cells and is shown in Aminian et al. [26]. Steady-state FANS equations were solved with a finite volume scheme using the commercial CFD code ANSYS FLUENT ${ }^{\circledR}$. The $\kappa-\epsilon$ model using all standard constants, except for $C_{\epsilon 1}$, which was set to 1.6 instead of 1.44 to compensate for the round-jet/plane-jet anomaly [42], was employed. Information on the performance of more turbulence models can be found in Aminian et al. [22]. The KEE-58 oxidation mechanism (17 species and 58 reversible reactions) [43] was used to treat $\mathrm{CH}_{4} / \mathrm{H}_{2}$ oxidation, as it was found to provide satisfactory results for MILD combustion modeling [22] [39]. The interaction between turbulence and chemistry was handled through the EDC model [32]; however, in order to improve predictions, the fine structure residence time constant, which equals to $C_{\tau}=0.4083$, was set to $C_{\tau}=1.5[26]$ and [25]. The impact of such modification on predictions is discussed in Aminian et al.[22]. The discrete ordinate (DO) method together with the Weighted-Sumof-Gray-Gases (WSGG) model with coefficients taken from Smith et al. [44] was employed to solve the radiative transfer equation (RTE) in 16 different directions across the computational domain. A zero-shear stress wall was adopted at the side boundary, instead of a more realistic pressure inlet/outlet conditions, in order to facilitate calculations. However, as the tunnel air was considered wide enough, this boundary condition does not affect the flame structure [26]. NO entering with the coflow was considered, setting the boundary condition from experimental data profile of NO mass fraction taken close to the entrance, i.e. at axial coordinate $z=4 \mathrm{~mm},[11]$. Subsequently, other simulations were carried out imposing the experimental data profile at $z=4 \mathrm{~mm}$ of temperature and main species for the fuel jet and coflow, instead of the fixed values reported in Table 1. Uniform velocities were set for the unmixed fuel jet and coflow oxidizer and are reported in Table 1 . The turbulence levels of all three inlet streams was adapted to better capture the development of the mixing layers[45] [23][26].

\subsection{NO formation models}

As mentioned in the introduction, the low mean and fluctuating temperatures of MILD combustion significantly modifies the NOx formation processwith respect to conventional combustion. Therefore, NO calculations were carried out by considering the $\mathrm{N}_{2} \mathrm{O}$ intermediate and NNH routes in addition to the thermal and prompt formation mechanisms. Four different models were used, which are: 
1. model A - global schemes for thermal, prompt, $\mathrm{N}_{2} \mathrm{O}$ and $\mathrm{NNH}$ formation routes;

2. model B - global scheme for prompt formation and comprehensive model from Löffler et al. [40];

3. model C1 - global scheme for prompt formation and comprehensive model derived for JHC conditions on the basis of POLIMI kinetic scheme [46];

4. model $\mathrm{C} 2$ - global scheme for prompt formation and comprehensive model derived for JHC conditions on the basis of Glarborg kinetic scheme [47].

Model A considers global mechanisms for thermal, prompt, $\mathrm{N}_{2} \mathrm{O}$ and $\mathrm{NNH}$ formation routes. The thermal NO formation was evaluated from the Zeldovich mechanism as :

$$
\frac{d[N O]_{\text {thermal }}}{d t}=k_{\text {thermal }}[O]\left[N_{2}\right]
$$

The prompt NO formation is evaluated through a single-step global reaction mechanism suggested for methane [48]:

$$
\frac{d[N O]_{\text {prompt }}}{d t}=k_{\text {prompt }}\left[O_{2}\right]^{a}\left[N_{2}\right][F]
$$

where $F$ denotes the fuel. $k_{\text {prompt }}$ depends on the fuel and the oxygen reaction order $a$ on oxygen mole fraction in flame [48]. The $\mathrm{NO}$ formation through intermediate specie $\mathrm{N}_{2} \mathrm{O}$ was determined according to Malte and Pratt [36] [49] as:

$$
\frac{d[N O]_{N 2 O}}{d t}=2\left(k_{N 2 O, f 2}\left[N_{2} O\right][O]-k_{N 2 O, r 2}[N O]^{2}\right)
$$

where

$$
\left[N_{2} O\right]=\frac{2 k_{N 2 O, f 1}\left[N_{2}\right][O][M]+k_{N 2 O, r 2}[N O]^{2}}{k_{N 2 O, r 1}[M]+k_{N 2 O, f 2}[O]}
$$

T

bespoke $\mathrm{C}$ subroutine following the global scheme proposed by Konnov [50].

$$
\frac{d[N O]_{N N H}}{d t}=2 k_{N N H}\left[N_{2}\right][O] X_{H}
$$

where $k_{N N H}=2.310^{-15} \exp -3600 / T \mathrm{~cm}^{3} \mathrm{~mol}^{-1} \mathrm{~s}^{-1}$ and $X_{H}$ is the mole fraction of $\mathrm{H}$ atoms. All reaction rates are integrated over PDF of temperature to take into account the effect of turbulent fluctuations on formation rates.

Model B was taken from Löffler et al. [40]. The model was derived for $\mathrm{CH}_{4} /$ air flame in one-dimensional plug flow reactor (PFR) operating at ambient pressure and $T=1873 \mathrm{~K}$ 
and is based on 21 reversible reactions and on the quasi-steady state assumption for $\mathrm{N}, \mathrm{N}_{2} \mathrm{O}$, $\mathrm{NNH}$ and $\mathrm{NH}$. The model includes thermal $\mathrm{NO}$ formation, $\mathrm{N}_{2} \mathrm{O}$ and $\mathrm{NNH}$ route; hence, the prompt NO route evaluated according to (2) is added to the model.

Model $\mathrm{C} 1$ and model $\mathrm{C} 2$ were derived in the present work for the JHC conditions starting from the kinetic schemes of POLIMI [46] and Glarborg [47], respectively. The models are described in the following section.

\section{Development of $\mathrm{C} 1$ and C2 schemes for NO calculation}

Two new reduced NO formation models are developed for the specific conditions of the Jet in Hot Coflow (JHC) burner, fed with a $\mathrm{CH}_{4} / \mathrm{H}_{2}$ mixture. Both models combine thermal $\mathrm{NO}$ formation, $\mathrm{N}_{2} \mathrm{O} / \mathrm{NO}$ and $\mathrm{NNH}$ route. Prompt $\mathrm{NO}$ formation is neglected because it may be estimated very simply in a commercial CFD package.

\subsection{OpenSmoke model}

The first step to create a new comprehensive model is the evaluation of the main reactions leading to NO formation under MILD combustion conditions during the oxidation of the mixture. To do that, the open-source software OpenSMOKE [51] was used, since it is a collection of numerical tools for the kinetic analysis of reacting systems (ideal reactors, i.e. Plug Flow Reactors, batch, Perfectly Stirred Reactors, shock-tube; laminar flames, i.e. counter-flow diffusion flames, premixed flat flames, steady-state flamelets) with complex kinetic mechanisms. The oxidation of the fuel mixture has been investigated in a onedimensional Perfectly Stirred Reactor (PSR) using two different detailed kinetic schemes:

- POLIMI mechanism [52] (109 species and 1882 reactions).

- Glarborg mechanism [47] (66 species and 449 reactions).

Both mechanisms consider the interactions between NO based and C1-C3 hydrocarbons. The derivation of the POLIMI mechanism was largely based on the Glarborg mechanism [53], however it was updated to better predict the laminar flame speed for systems containing hydrogen, methane and carbon monoxide as well as for fuel-rich conditions. As a matter of fact the two schemes are expected to show minor differences for MILD combustion.

The reaction conditions are listed in Table 2 . The residence time $\tau$, was estimated from the JHC CFD calculations as the time needed to reach the downstream location at $z=120$ 
252

253

$\mathrm{mm}$ from the burner. For each run, temperature $T$ and pressure $p$ have been fixed inside the PSR, so OpenSMOKE can linearize Arrhenius equations and carry out a sensitivity analysis of the main reactions taking place in the reactor (Rate Of Production Analysis, ROPA).

\subsection{C1 model}

The results of the ROPA analysis are very similar for flames HM1, HM2 and for any temperature chosen in the range 1300 - $1700 \mathrm{~K}$. The main reactions involved in NO formation obtained with ROPA approach are listed in Figure 2a. The analysis shows that under JHC combustion conditions, so for temperature below $1700 \mathrm{~K}$ and locally fuel-rich flame, NO formation may occur via different routes. In fact, it is possible to notice that $\mathrm{NO}_{2}, \mathrm{~N}_{2} \mathrm{O}$ and $\mathrm{HNO}$ are significant intermediates for NO formation and, differently from Löffler et al. mechanism [40], not completely converted back. Thus, $\mathrm{NNH} / \mathrm{NH}$ and $\mathrm{N}_{2} \mathrm{O} / \mathrm{NO}$ routes become important, while thermal NO is not so relevant at these temperatures.

The ROPA was applied to evaluate the main reactions involving the intermediate species $\mathrm{N}, \mathrm{N}_{2} \mathrm{O}, \mathrm{NO}_{2}, \mathrm{NNH}, \mathrm{NH}, \mathrm{HNO}, \mathrm{NH}_{2}, \mathrm{NH}_{3}$. The formation of $\mathrm{N}$ is kinetically limited by the break-up of the $\mathrm{N}_{2}$ triple bond, so it is possible to assume quasi-steady-state concentration for it. Similar hypothesis can be made for $\mathrm{N}_{2} \mathrm{O}$ and $\mathrm{NNH}$ because they are formed and converted back to $\mathrm{N}_{2}$ rapidly and the reactions forming $\mathrm{NO}$ from these species are relative slow. The same assumption is made for $\mathrm{NH}$ and the other radicals, which may at least hold at high radical concentrations or high temperature, where NO formation is significant. Thus, the concentration of these species can be obtained by a set of algebraic equations, linear in terms of the unknowns, which can be solved analytically. The reverse rate constants are obtained through OpenSMOKE [51]. The kinetics of forward and backward reactions, i.e. $k_{f}$ and $k_{r}$, are given in Table 3 .

$$
[N]=\frac{k_{r 1}[O]\left[N_{2}\right]+k_{r 2}[N O][O]+k_{r 3}[N O][C O]+k_{f 4}[N H][H]}{k_{f 1}[N O]+k_{r 2}\left[O_{2}\right]+k_{f 3}\left[C_{2}\right]+k_{r 4}\left[H_{2}\right]}
$$

$$
\left[N_{2} O\right]=\frac{k_{r 5}[O]\left[N_{2}\right][M]+k_{r 6}\left[N_{2}\right][O H]+k_{r 7}\left[N_{2}\right]\left[C O_{2}\right]}{k_{f 5}[M]+k_{f 6}[H]+k_{f 7}[C O]}
$$

$$
[N H]=\frac{k_{r 13}\left[N_{2} O\right][H]+k_{f 14}\left[N H_{2}\right][H]+k_{r 15}[N O][O H]+k_{f 16}[N N H][O]}{[N O]\left(k_{f 13}+k_{r 16}\right)+k_{r 14}\left[H_{2}\right]+k_{f 15}\left[O_{2}\right]}
$$




$$
[H N O]=\frac{[N O]\left(k_{r 9}\left[H_{2}\right]+k_{f 10}[H C O]+k_{f 11}[H][M]\right)+k_{f 12}[N H]\left[O_{2}\right]}{k_{f 9}[H]+k_{r 10}[C O]+k_{r 11}[M]+k_{r 12}[O]}
$$

255

$$
\left[\mathrm{NO}_{2}\right]=\frac{[\mathrm{NO}]\left(k_{f 23}\left[\mathrm{HO}_{2}\right]+k_{r 24}\left[\mathrm{CH}_{3} \mathrm{O}\right]+k_{r 25}[\mathrm{OH}]\right)}{k_{r 23}[\mathrm{OH}]+k_{f 24}\left[\mathrm{CH}_{3}\right]+k_{f 25}[\mathrm{H}]}
$$

256

$$
\left[\mathrm{NH}_{2}\right]=\frac{\left[\mathrm{NH}_{3}\right]\left(k_{f 17}[\mathrm{H}]+k_{f 30}\left[\mathrm{CH}_{3}\right]+k_{f 19}[\mathrm{OH}]\right)+k_{r 14}[\mathrm{NH}]\left[\mathrm{H}_{2}\right]}{k_{r 17}\left[\mathrm{H}_{2}\right]+k_{r 30}\left[\mathrm{CH}_{4}\right]+k_{r 19}\left[\mathrm{H}_{2} \mathrm{O}\right]+k_{f 14}[\mathrm{H}]}
$$

257

$$
\left[\mathrm{NH}_{3}\right]=\frac{\left[\mathrm{NH}_{2}\right]\left(k_{r 17}\left[\mathrm{H}_{2}\right]+k_{r 30}\left[\mathrm{CH}_{4}\right]+k_{r 19}\left[\mathrm{H}_{2} \mathrm{O}\right]\right)}{k_{f 17}[\mathrm{H}]+k_{f 30}\left[\mathrm{CH}_{3}\right]+k_{f 19}[\mathrm{OH}]}
$$

258

$$
[N N H]=\frac{\left[N_{2}\right]\left(k_{r 20}\left[\mathrm{HO}_{2}\right]+k_{r 21}[H]+k_{r 22}[H]\left[\mathrm{O}_{2}\right]\right)}{k_{f 20}\left[\mathrm{O}_{2}\right]+k_{f 21}+k_{f 22}\left[\mathrm{O}_{2}\right]}
$$

269

270

The concentrations of $\mathrm{O}_{2}, \mathrm{~N}_{2}, \mathrm{H}_{2}, \mathrm{H}_{2} \mathrm{O}, \mathrm{O}, \mathrm{H}, \mathrm{OH}, \mathrm{HO}_{2}, \mathrm{CH}_{3}, \mathrm{CH}_{4}, \mathrm{CO}, \mathrm{CO}_{2}, \mathrm{HCO}, \mathrm{CH}_{2} \mathrm{O}$ are obtained from the gas-phase oxidation mechanism. Finally, the rate of NO formation is given by:

$$
\begin{aligned}
\frac{d[N O]}{d t}= & \left(k_{r 1}[\mathrm{O}]\left[\mathrm{N}_{2}\right]+k_{f 2}\left[\mathrm{O}_{2}\right][\mathrm{N}]-k_{f 1}[\mathrm{~N}][\mathrm{NO}]+k_{r 2}[\mathrm{NO}][\mathrm{O}]\right)+ \\
& +\left(k_{f 25}\left[\mathrm{NO}_{2}\right][\mathrm{H}]+k_{f 24}\left[\mathrm{CH}_{3}\right]\left[\mathrm{NO}_{2}\right]-k_{f 23}[\mathrm{NO}]\left[\mathrm{HO}_{2}\right]\right)+ \\
& +\left(k_{r 13}\left[\mathrm{~N}_{2} \mathrm{O}\right][\mathrm{H}]+k_{f 16}[\mathrm{NNH}][\mathrm{O}]+k_{f 15}[\mathrm{NH}]\left[\mathrm{O}_{2}\right]+k_{f 30}[\mathrm{NH}][\mathrm{O}]\right)+ \\
& +\left(2 k_{f 26}\left[\mathrm{~N}_{2} \mathrm{O}\right][\mathrm{O}]-k_{r 26}[\mathrm{NO}][\mathrm{NO}]\right)
\end{aligned}
$$

\subsection{C2 model}

The development of the $\mathrm{C} 2$ model from the Glarborg mechanism is based on the same procedure explained in the previous subsection. Results from ROPA are shown in Figure $2 \mathrm{~b}$. The main reactions involved in NO formation, are quite similar to those identified in the previous model. The kinetic parameters of the resulting mechanism are provided in Table 4. ROPA was applied for the intermediate species, so that the following algebraic equations were obtained.

$$
[N]=\frac{k_{r 1}[O]\left[N_{2}\right]+k_{r 2}[N O][O]+k_{r 3}[N O][C O]+k_{f 4}[N H][H]}{k_{f 1}[N O]+k_{r 2}\left[O_{2}\right]+k_{f 3}\left[C_{2}\right]+k_{r 4}\left[H_{2}\right]}
$$

$$
\left[N_{2} \mathrm{O}\right]=\frac{k_{r 5}[\mathrm{O}]\left[\mathrm{N}_{2}\right][\mathrm{M}]+k_{r 6}\left[\mathrm{~N}_{2}\right][\mathrm{OH}]+k_{r 7}\left[\mathrm{~N}_{2}\right]\left[\mathrm{CO}_{2}\right]+k_{r 8}\left[\mathrm{~N}_{2}\right]\left[\mathrm{HO}_{2}\right]}{k_{f 5}[\mathrm{M}]+k_{f 6}[\mathrm{H}]+k_{f 7}[\mathrm{CO}]+k_{f 8}[\mathrm{OH}]}
$$

$$
[N H]=\frac{k_{r 13}\left[N_{2} O\right][H]+k_{f 14}\left[N_{2}\right][H]+k_{r 15}[N O][O H]+k_{f 16}[N N H][O]+k_{r 12}[H N O][O]}{[N O]\left(k_{f 13}+k_{r 16}\right)+k_{r 14}\left[H_{2}\right]+\left[O_{2}\right]\left(k_{f 15}+k_{f 12}\right)}
$$




$$
[H N O]=\frac{[N O]\left(k_{r 9}\left[H_{2}\right]+k_{f 10}[H C O]+k_{f 11}[H][M]\right)+k_{f 12}[N H]\left[O_{2}\right]}{k_{f 9}[H]+k_{r 10}[C O]+k_{r 11}[M]+k_{r 12}[O]}
$$

272

273

$$
\left[N H_{2}\right]=\frac{\left[N H_{3}\right]\left(k_{f 17}[H]+k_{f 18}[O]+k_{f 19}[O H]\right)+k_{r 14}[N H]\left[H_{2}\right]}{k_{r 17}\left[H_{2}\right]+k_{r 18}[O H]+k_{r 19}\left[H_{2} O\right]+k_{f 14}[H]}
$$

274

$$
\left[N H_{3}\right]=\frac{\left[N H_{2}\right]\left(k_{r 17}\left[H_{2}\right]+k_{r 18}[O H]+k_{r 19}\left[H_{2} O\right]\right)}{k_{f 17}[H]+k_{f 18}[O]+k_{f 19}[O H]}
$$

275

$$
[N N H]=\frac{\left[N_{2}\right]\left(k_{r 20}\left[\mathrm{HO}_{2}\right]+k_{r 21}[\mathrm{H}]+k_{r 22}[\mathrm{H}]\left[\mathrm{O}_{2}\right]\right)}{k_{f 20}\left[\mathrm{O}_{2}\right]+k_{f 21}+k_{f 22}\left[\mathrm{O}_{2}\right]}
$$

Finally, the rate of NO formation is given by:

$$
\begin{aligned}
\frac{d[N O]}{d t}= & \left(k_{r 1}[O]\left[N_{2}\right]+k_{f 2}\left[\mathrm{O}_{2}\right][N]-k_{f 1}[N][N O]+k_{r 2}[N O][O]\right)+ \\
& +\left(k_{f 25}\left[N O_{2}\right][H]+k_{f 9}[H N O][H]-k_{f 23}[N O]\left[H O_{2}\right]-k_{f 10}[H C O][N O]\right)+ \\
& +\left(k_{r 13}\left[N_{2} O\right][H]+k_{f 16}[N N H][O]+k_{f 15}[N H]\left[O_{2}\right]+k_{f 30}[N H][O]\right)+ \\
& +\left(2 k_{f 26}\left[N_{2} O\right][O]-k_{r 26}[N O][N O]\right)
\end{aligned}
$$

\section{Results}

As mentioned previously, an accurate validation of the NO formation models demands for a good prediction of the thermochemical field, which is the basis for the post-processing calculation of pollutants. Hence the first part of this section will be devoted at discussing the fidelity of the CFD model.

\subsection{Validation of numerical model}

Figure 3 shows the comparison between experimental radial profiles of temperature and chemical species $\left(\mathrm{O}_{2}, \mathrm{OH}\right.$ and $\left.\mathrm{CO}_{2}\right)$ mass fractions at different axial locations (i.e. $z=30$, 60 and $120 \mathrm{~mm}$ ) and those predicted from the CFD model for HM1, HM2, HM3 flames. More discussion about the modelling errors can be found in [22]. Dashed lines refer to simulations performed by imposing experimental profiles for the inlet BCs. No significant improvement over the baseline simulations (constant inlet profiles) can be observed. A 
very good predictions of the temperature and $\mathrm{O}_{2}$ concentration profiles is achieved at all locations (see Figure 3a and Figure 3b, respectively). Such agreement was the result of the tuning of the inlet turbulence levels conditions, performed to better capture the three stream mixing [18] [23] [26], as well as of the revision of the original EDC model to treat the turbulence/chemistry interaction [22]. In particular the latter modification allowed reducing the large overestimation of temperature at the downstream location $z=120 \mathrm{~mm}$, observed with the original EDC model.

The predictivity of $\mathrm{CO}_{2}$ (Figure 3d) is very good, except for a slight overprediction near the axis at $z=120 \mathrm{~mm}$. As for $\mathrm{OH}$ concentration (Figure 3c) it can be observed an underestimation of the peak value near the burner and an overestimation downstream. However the trend is well captured. More discussion about the prediction of minor species can be found in Aminian et al. [26].

\section{2. $N O_{x}$ predictions}

Figure 4 shows the comparison between radial profiles of experimental NO and those predicted by the different models, namely A, B, C1 and C2, for the HM1 flame at different locations. The influence of inlet boundary conditions is also illustrated by comparing the case with constant value and experimental profile boundary conditions. It can be observed that at $z=30$ and $z=60 \mathrm{~mm}$ all models predict similar profiles. However at $z=120$ mm, results obtained with the $\mathrm{C} 1$ and $\mathrm{C} 2$ models follow more closely measurements than the $\mathrm{A}$ and $\mathrm{B}$ models. It can be noticed that all models underpredict NO concentration at $z=30$ and $z=60 \mathrm{~mm}$ whereas they systematically overpredict NO emission downstream at $z=120 \mathrm{~mm}$. Little better results have been achieved imposing the radial profiles of the main species and temperature as boundary conditions for coflow, instead of setting constant values (i.e. flat profiles). This behaviour may be partly imputed to errors in the prediction of $\mathrm{OH}$ concentration illustrated in Figure 3c. Closer to the burner, CFD results underestimate $\mathrm{OH}$ concentration. Therefore, the first reaction $\mathrm{HO}_{2}+\mathrm{NO} \rightleftarrows \mathrm{NO}_{2}+\mathrm{OH}$ is shifted towards the right hand side, resulting in larger consumption of NO, leading of an underprediction of $\mathrm{NO}$ emissions. Conversely, the $\mathrm{OH}$ overprediction at $z=120 \mathrm{~mm}$ leads to lower NO consumption and thus larger predicted NO values. Similar comments can be made regarding the HM2 and HM3 flames, shown in Figure 5 and Figure 6, respectively. Predictions of NO emissions at $z=60 \mathrm{~mm}$ were satisfactory. Peak value of approximately 11 ppm were estimated by the $\mathrm{C} 1$ and $\mathrm{C} 2$ models for the HM2 flame, thus in good agreement 
with the experimental peak value of $13 \mathrm{ppm}$. Also for HM3 flame, the $z=60 \mathrm{~mm}$ location was well captured.

For $z=120 \mathrm{~mm}$, however, predictions indicated an overestimation of $\mathrm{NO}$ emissions. In particular the experimental peak NO values at $z=120 \mathrm{~mm}$ were found to increase from 4 to $22 \mathrm{ppm}$ when increasing the oxygen content from $3 \%$ to $9 \%$ (i.e., moving from HM1 to HM3 flames), whereas the predicted NO peak values increased from 4.5 to $45 \mathrm{ppm}$. The reason for such overestimation of $\mathrm{NO}$ emissions at $z=120 \mathrm{~mm}$ may be partly imputed to the $\mathrm{OH}$ over prediction mentioned above. Moreover it is also worth noting that temperature profiles at $z=120 \mathrm{~mm}$ are overestimated by the model (see Figure 3 ) and this can affect the accuracy of the NO calculation. As mentioned in Section 5.1 such temperature overestimation at downstream is largely reduced with respect to that observed with the original EDC model; however, some discrepancy still exists. As a matter of fact, however the NO overestimation was less evident with the $\mathrm{C} 1$ and $\mathrm{C} 2$ models than for $\mathrm{A}$ and $\mathrm{B}$ models. In particular at $z=120 \mathrm{~mm}$ the B model predicted peak NO values which were about three times higher than the experimental ones for both HM2 and HM3 flames.

However, on the whole, it is possible to summary that experimental data are predicted in a satisfactory manner by these models, especially considering the order of magnitude of No emissions (a few ppm). As a matter of fact, the $\mathrm{C} 1$ and $\mathrm{C} 2$ models were derived from a ROPA analysis based on conditions of HM1 and HM2; however results indicate that they are fairly suited also for the conditions of HM3 flame, which are characterized by higher oxygen content and thus deviate from strictly MILD conditions. The relative importance of the different NO formation routes is shown in Figures 7 as calculated in the outlet section for the three flames and with all models. It can be observed that the thermal route is no dominant in all cases, due to the low temperatures, typical of MILD combustion. Prompt pathway is the major source of NO (about $50 \%$ of the total) because of the local fuel-rich conditions. This partly explains the small differences between the models investigated in the present work, as all model include the same prompt scheme. Beside it, $\mathrm{N}_{2} \mathrm{O}$ and $\mathrm{NNH}$ routes play an important role in the overall NO formation. The former has great percentage importance in HM1 (about 20\% in B mechanism), but decreases with increasing oxygen ( $9 \%$ in HM2 and 5\% in HM3). The NNH route is expected to be important because of the availability of $\mathrm{H}$ radicals in the flame. In particular, the $\mathrm{NNH}$ contribution appears to be stable at around $20 \%$ in each flame and in B, C1 and C2 mechanisms. Based on C1 and 
$\mathrm{C} 2$ results, it can be noticed the importance of $\mathrm{HNO}$ and $\mathrm{NO}_{2}$ route $(11 \%$ in $\mathrm{HM} 1,10 \%$ in HM2 and 7\% in HM3), which thus cannot be neglected in MILD combustion conditions.

The evolution of NO formation paths at $z=120 \mathrm{~mm}$ for HM1 flame is reported in Figure 8 as predicted using $\mathrm{C} 1$ and $\mathrm{C} 2$ models. It can be observed a good agreement between the two models. Moreover it is evident that in such location the highest contributions to NO come from the prompt and NNH intermediate paths. The percentage contribution of the NNH route to the total NO formation is reported in Figure 9 for the three flames and for the C1 and C2 models. Again, the good agreement between the two models is observed. The inclusion of NNH route appears crucial as in some locations it can contribute to more than $50 \%$ of total NO emissions.

\section{Conclusions}

Two reduced NO mechanisms to be used for a quick calculation of pollutants emission through post-processing of CFD results, have been derived for MILD combustion conditions starting from a ROPA analysis based on POLIMI [46] and Glarborg [47] kinetic schemes. The resulting reduced mechanisms incorporate thermal, $\mathrm{N}_{2} \mathrm{O}, \mathrm{NNH}$ as well as $\mathrm{HNO} / \mathrm{NO}_{2}$ intermediate routes. The two models were found to give very similar predictions with a very good matching of in-flame NO measurements for three different levels of $\mathrm{O}_{2}$ content. This indicates a good applicability of the models across a wide range of MILD combustion conditions. For such cases the thermal mechanism was found to be almost negligible. The NNH intermediate path was found to play a significant role, in some locations contributing to more than $50 \%$ of total NO. However as a matter fo fact, such scheme is usually not included in commercial CFD codes. The availability of reduced models incorporating different NO formation routes is expected to be very useful for the design of large-scale industrial systems.

\section{References}

[1] A. Cavaliere, M. de Joannon, Mild combustion, Prog Energy Combust Sci 30 (2004) $329-366$.

[2] G.-M. Choi, M. Katsuki, Advanced low NOx combustion using highly preheated air, Energy Convers Manag 42 (5) (2001) 639 - 652. 
[3] M. Derudi, A. Villani, R. Rota, Sustainability of mild combustion of hydrogencontaining hybrid fuels, Proc Combust Inst 31 (2) (2007) 3393 - 3400.

[4] S. Hosseini, M. Wahid, A. Abuelnuor, Biogas flameless combustion: A review, Appl Mech Mater 388 (2013) 273-279.

[5] S. Chen, C. Zheng, Counterflow diffusion flame of hydrogen-enriched biogas under MILD oxy-fuel condition, Int J Hydrog Energy 36 (23) (2011) 15403 - 15413.

[6] C. Galletti, A. Parente, M. Derudi, R. Rota, L. Tognotti, Numerical and experimental analysis of NO emissions from a lab-scale burner fed with hydrogen-enriched fuels and operating in MILD combustion, Int J Hydrog Energy 34 (19) (2009) 8339 - 8351.

[7] A. Parente, C. Galletti, L. Tognotti, Effect of the combustion model and kinetic mechanism on the MILD combustion in an industrial burner fed with hydrogen enriched fuels, Int J Hydrog Energy 33 (24) (2008) 7553 - 7564.

[8] A. Parente, C. Galletti, J. Riccardi, M. Schiavetti, L. Tognotti, Experimental and numerical investigation of a micro-CHP flameless unit, Appl Energy 89 (1) (2012) 203 $-214$.

[9] M. Ayoub, C. Rottier, S. Carpentier, C. Villermaux, A. Boukhalfa, D. Honoré, An experimental study of mild flameless combustion of methane/hydrogen mixtures, Int $\mathrm{J}$ Hydrog Energy 37 (8) (2012) 6912 - 6921.

[10] Y. Yu, W. Gaofeng, L. Qizhao, M. Chengbiao, X. Xianjun, Flameless combustion for hydrogen containing fuels, Int J Hydrog Energy 35 (7) (2010) 2694 - 2697.

[11] B. Dally, A. Karpetis, R. Barlow, Structure of turbulent non-premixed jet flames in a diluted hot coflow, Proc Combust Inst 29 (1) (2002) 1147 - 1154.

[12] B. Dally, E. Riesmeier, N. Peters, Effect of fuel mixture on moderate and intense low oxygen dilution combustion, Combust Flame 137 (4) (2004) 418 - 431.

[13] P. R. Medwell, P. A. Kalt, B. B. Dally, Simultaneous imaging of OH, formaldehyde, and temperature of turbulent nonpremixed jet flames in a heated and diluted coflow, Combust Flame 148 (1-2) (2007) $48-61$. 
[14] P. R. Medwell, B. B. Dally, Effect of fuel composition on jet flames in a heated and diluted oxidant stream, Combust Flame 159 (10) (2012) 3138 - 3145.

[15] E. Oldenhof, M. Tummers, E. van Veen, D. Roekaerts, Ignition kernel formation and lift-off behaviour of jet-in-hot-coflow flames, Combust Flame 157 (6) (2010) 1167 1178 .

[16] E. Oldenhof, M. Tummers, E. van Veen, D. Roekaerts, Role of entrainment in the stabilisation of jet-in-hot-coflow flames, Combust Flame 158 (8) (2011) 1553 - 1563.

[17] E. Oldenhof, M. J. Tummers, E. H. van Veen, D. J. Roekaerts, Transient response of the delft jet-in-hot coflow flames, Combust Flame 159 (2) (2012) 697 - 706.

[18] F. Christo, B. Dally, Modeling turbulent reacting jets issuing into a hot and diluted coflow, Combust Flame 142 (1-2) (2005) 117 - 129.

[19] S. H. Kim, K. Y. Huh, B. Dally, Conditional moment closure modeling of turbulent nonpremixed combustion in diluted hot coflow, Proc Combust Inst 30 (1) (2005) 751 757.

[20] A. Mardani, S. Tabejamaat, S. Hassanpour, Numerical study of $\mathrm{CO}$ and $\mathrm{CO} 2$ formation in CH4/H2 blended flame under MILD condition, Combust Flame 160 (9) (2013) 1636 -1649 .

[21] A. Mardani, S. Tabejamaat, Effect of hydrogen on hydrogenmethane turbulent nonpremixed flame under \{MILD\} condition, Int J Hydrog Energy 35 (20) (2010) 11324 11331.

[22] J. Aminian, C. Galletti, S. Shahhosseini, L. Tognotti, Numerical investigation of a mild combustion burner: Analysis of mixing field, chemical kinetics and turbulencechemistry interaction, Flow, Turbulence and Combustion 88 (4) (2012) 597-623.

[23] A. Frassoldati, P. Sharma, A. Cuoci, T. Faravelli, E. Ranzi, Kinetic and fluid dynamics modeling of methane/hydrogen jet flames in diluted coflow, Appl Therm Eng 30 (4) (2010) $376-383$.

[24] F. Wang, J. Mi, P. Li, C. Zheng, Diffusion flame of a CH4/H2 jet in hot low-oxygen coflow, Int J Hydrog Energy 36 (15) (2011) 9267 - 9277. 
[25] A. De, E. Oldenhof, P. Sathiah, D. Roekaerts, Numerical simulation of delft-jet-inhot-coflow (DJHC) flames using the eddy dissipation concept model for turbulencechemistry interaction, Flow, Turbulence and Combustion 87 (4) (2011) 537-567.

[26] J. Aminian, C. Galletti, S. Shahhosseini, L. Tognotti, Key modeling issues in prediction of minor species in diluted-preheated combustion conditions, Appl Therm Eng 31 (16) (2011) $3287-3300$.

[27] M. Ihme, Y. C. See, LES flamelet modeling of a three-stream MILD combustor: Analysis of flame sensitivity to scalar inflow conditions, Proc Combust Inst 33 (1) (2011) $1309-1317$.

[28] R. M. Kulkarni, W. Polifke, LES of delft-jet-in-hot-coflow (DJHC) with tabulated chemistry and stochastic fields combustion model, Fuel Processing Technology 107 (0) (2013) $138-146$.

[29] Y. Afarin, S. Tabejamaat, Effect of hydrogen on h2/ch4 flame structure of mild combustion using the \{LES\} method, Int J Hydrog Energy 38 (8) (2013) 3447 - 3458.

[30] B. J. Isaac, A. Parente, C. Galletti, J. N. Thornock, P. J. Smith, L. Tognotti, A novel methodology for chemical time scale evaluation with detailed chemical reaction kinetics, Energy Fuels 27 (2013) $2255-2265$.

[31] B. F. Magnussen, On the structure of turbulence and a generalized eddy dissipation concept for chemical reaction in turbulent flow, in: 19th AIAA Aerospace Science Meeting, 1981.

[32] B. F. Magnussen, The eddy dissipation concept, a bridge between science and technology, in: Eccomas Thematic Conf on Computat Combust, 2005.

[33] G. Szegö, B. Dally, G. Nathan, Scaling of NOx emissions from a laboratory-scale mild combustion furnace, Combust Flame 154 (1-2) (2008) 281 - 295.

[34] P. Li, F. Wang, J. Mi, B. Dally, Z. Mei, J. Zhang, A. Parente, Mechanisms of NO formation in MILD combustion of CH4/H2 fuel blends, Int J Hydrog Energy 39 (33) (2014) $19187-19203$. 
[35] C. Fenimore, Formation of nitric oxide in premixed hydrocarbon flames, Proc Combust Inst 13 (1) (1971) $373-380$.

[36] P. Malte, D. Pratt, Measurement of atomic oxygen and nitrogen oxides in jet-stirred combustion, Proc Combust Inst 15 (1) (1975) $1061-1070$.

[37] A. Nicolle, P. Dagaut, Occurrence of no-reburning in MILD combustion evidenced via chemical kinetic modeling, Fuel 85 (1718) (2006) 2469 - 2478.

[38] J. W. Bozzelli, A. M. Dean, O + NNH: A possible new route for nox formation in flames, Int J Chem Kinet 27 (11) (1995) 1097-1109.

[39] A. Parente, C. Galletti, L. Tognotti, A simplified approach for predicting NO formation in MILD combustion of CH4-H2 mixtures, Proc Combust Inst 33 (2) (2011) 3343 - 3350.

[40] G. Löffler, R. Sieber, M. Harasek, H. Hofbauer, R. Hauss, J. Landauf, NOx formation in natural gas combustion-a new simplified reaction scheme for CFD calculations, Fuel 85 (4) (2006) $513-523$.

[41] X. Gao, F. Duan, S. C. Lim, M. S. Yip, NOx formation in hydrogen-methane turbulent diffusion flame under the moderate or intense low-oxygen dilution conditions, Energy $59(0)(2013) 559-569$.

[42] A. P. Morse, Axisymmetric turbulent shear flows with and without swirl, Ph.D. thesis, London University (1977).

[43] R. Bilger, S. Stårner, R. Kee, On reduced mechanisms for methane-air combustion in nonpremixed flames, Combust Flame 80 (1990) 135-149.

[44] T. Smith, Z. Shen, J. N. Friedman, Evaluation of coefficients for the weighted sum of gray gases model, J Heat Transf 104 (4) (1982) $602-608$.

[45] F. C. Christo, B. B. Dally, Modelling turbulent reacting jets issuing into a hot and diluted coflow, Combust Flame 142 (2005) 117-129.

[46] E. Ranzi, A. Sogaro, P. Gaffuri, G. Pennati, T. Faravelli, Wide range modeling study of methane oxidation, Combust Sci Technol 96 (4-6) (1994) 279-325. 
[47] P. Glarborg, M. U. Alzueta, K. Dam-Johansen, J. A. Miller, Kinetic modeling of hydrocarbon/nitric oxide interactions in a flow reactor, Combust Flame 115 (1-2) (1998) $1-27$.

[48] G. D. Soete, Overall reaction rates of NO and N2 formation from fuel nitrogen, Proc Combust Inst 15 (1) (1975) 1093 - 1102.

[49] Ansys 13, Fluent User's Guide.

[50] A. Konnov, G. Colson, J. D. Ruyck, The new route forming NO via NNH, Combust Flame 121 (3) (2000) $548-550$.

[51] A. Cuoci, A. Frassoldati, T. Faravelli, E. Ranzi, OpenSMOKE: Numerical modeling of reacting systems with detailed kinetic mechanisms, XXXIV Meeting of Italian Section of Comb Inst (2011).

[52] A. Cuoci, A. Frassoldati, T. Faravelli, E. Ranzi, Formation of soot and nitrogen oxides in unsteady counterflow diffusion flames, Combust Flame 156 (10) (2009) 2010 - 2022.

[53] T. Faravelli, A. Frassoldati, E. Ranzi, Kinetic modeling of the interactions between NO and hydrocarbons in the oxidation of hydrocarbons at low temperatures, Combustion and Flame 132 (12) (2003) $188-207$. 
Table 1: Operating conditions for cases studied (compositions are as mass fractions)

\begin{tabular}{c|ccccc|cccccc}
\hline & \multicolumn{7}{|c|}{ Fuel jet $)$} & \multicolumn{7}{c}{ Oxidant coflow } \\
\hline Case & $R e$ & $T$ & $\mathrm{CH}_{4}$ & $\mathrm{H}_{2}$ & $u$ & $T$ & $\mathrm{O}_{2}$ & $\mathrm{~N}_{2}$ & $\mathrm{H}_{2} \mathrm{O}$ & $\mathrm{CO}_{2}$ & $u$ \\
& $(-)$ & $(\mathrm{K})$ & $(\%)$ & $(\%)$ & $(\mathrm{m} / \mathrm{s})$ & $(\mathrm{K})$ & $(\%)$ & $(\%)$ & $(\%)$ & $(\%)$ & $(\mathrm{m} / \mathrm{s})$ \\
\hline HM1 & 10,000 & 305 & 88 & 11 & 58.74 & 1300 & 3 & 85 & 6.5 & 5.5 & 3.2 \\
HM2 & 10,000 & 305 & 88 & 11 & 58.74 & 1300 & 6 & 82 & 6.5 & 5.5 & 3.2 \\
HM3 & 10,000 & 305 & 88 & 11 & 58.74 & 1300 & 9 & 79 & 6.5 & 5.5 & 3.2 \\
\hline
\end{tabular}

Table 2: PSR operating conditions

\begin{tabular}{cccc}
\hline \multirow{2}{*}{ Inlet Stream } & \multicolumn{3}{c}{ Flame } \\
\cline { 2 - 4 } & HM1 & HM2 & HM3 \\
\hline $\mathrm{H}_{2}$ (\% by wt.) & 7.14 & 7.11 & 7.09 \\
$\mathrm{CH}_{4}$ (\% by wt.) & 5.71 & 5.69 & 5.67 \\
$\mathrm{O}_{2}$ (\% by wt.) & 2.81 & 5.61 & 8.41 \\
$\mathrm{CO}_{2}$ (\% by wt.) & 5.14 & 5.14 & 5.14 \\
$\mathrm{H}_{2} \mathrm{O}$ (\% by wt.) & 6.08 & 6.08 & 6.08 \\
$p$ (atm) & 1 & 1 & 1 \\
$T$ (K) & $1300-1700$ & $1300-1700$ & $1300-1700$ \\
$\tau$ (ms) & 52 & 52 & 52 \\
\hline
\end{tabular}


Table 3: Kinetic parameters applied to $\mathrm{C} 1$ model in JHC conditions. Units: mol, cm, s, cal.

\begin{tabular}{|c|c|c|c|c|c|c|}
\hline \multirow{2}{*}{ Reaction $^{a}$} & \multicolumn{3}{|c|}{ Forward } & \multicolumn{3}{|c|}{ Backward } \\
\hline & $A$ & $\beta$ & $E_{a}$ & $A$ & $\beta$ & $E_{a}$ \\
\hline 1. $N+N O \rightleftarrows N_{2}+O$ & $3.30 \cdot 10^{12}$ & 0.3 & 0 & $1.71 \cdot 10^{14}$ & 0.0 & 72887 \\
\hline 2. $\mathrm{N}+\mathrm{O}_{2} \rightleftarrows \mathrm{NO}+\mathrm{O}$ & $6.40 \cdot 10^{9}$ & 1 & 6280 & $4.92 \cdot 10^{12}$ & 0.0 & 38758 \\
\hline 3. $\mathrm{CO}_{2}+\mathrm{N} \rightleftarrows \mathrm{NO}+\mathrm{CO}$ & $1.90 \cdot 10^{11}$ & 0 & 20237 & $2.16 \cdot 10^{3}$ & 0.9 & 26372 \\
\hline 4. $N H+H \rightleftarrows N+H_{2}$ & $3.00 \cdot 10^{13}$ & 0 & 0 & $1.38 \cdot 10^{14}$ & 0 & 23533 \\
\hline 5. $\mathrm{N}_{2} \mathrm{O}+\mathrm{M \rightleftarrows} \mathrm{N}_{2}+\mathrm{O}+\mathrm{M}$ & $4.00 \cdot 10^{8}$ & 0 & 56100 & $3.74 \cdot 10^{4}$ & 1.09 & 25264 \\
\hline 6. $\mathrm{N}_{2} \mathrm{O}+\mathrm{H \rightleftarrows} \mathrm{N}_{2}+\mathrm{OH}$ & $3.30 \cdot 10^{10}$ & 0 & 4729 & $2.96 \cdot 10^{1}$ & 1.3 & 66092 \\
\hline 7. $\mathrm{N}_{2} \mathrm{O}+\mathrm{CO} \rightleftarrows \mathrm{N}_{2}+\mathrm{CO}_{2}$ & $2.70 \cdot 10^{11}$ & 0 & 20237 & $6.96 \cdot 10^{8}$ & 0.1 & 107481 \\
\hline 9. $\mathrm{HNO}+\mathrm{H} \rightleftarrows \mathrm{H}_{2}+\mathrm{NO}$ & $4.40 \cdot 10^{11}$ & 0.72 & 655 & $7.48 \cdot 10^{6}$ & 1.2 & 54457 \\
\hline 10. $\mathrm{HCO}+\mathrm{NO} \rightleftarrows \mathrm{HNO}+\mathrm{CO}$ & $7.20 \cdot 10^{12}$ & 0 & 0 & $2.93 \cdot 10^{10}$ & 0.1 & 34525 \\
\hline 11. $H+N O+M \rightleftarrows H N O+M$ & $4.00 \cdot 10^{20}$ & -1.75 & 0 & $1.40 \cdot 10^{19}$ & -1.97 & 49824 \\
\hline 12. $\mathrm{NH}+\mathrm{O}_{2} \rightleftarrows H N O+O$ & $1.30 \cdot 10^{7}$ & 1.5 & 100 & $1.37 \cdot 10^{2}$ & 1.68 & 55902 \\
\hline 13. $\mathrm{NH}+\mathrm{NO} \rightleftarrows \mathrm{N}_{2} \mathrm{O}+\mathrm{H}$ & $4.32 \cdot 10^{14}$ & -0.5 & 0 & $9.56 \cdot 10^{17}$ & -1.6 & 35932 \\
\hline 14. $\mathrm{NH}_{2}+H \rightleftarrows N H+H_{2}$ & $4.00 \cdot 10^{13}$ & 3650 & 0 & $5.24 \cdot 10^{9}$ & 0.2 & 15670 \\
\hline 15. $\mathrm{NH}+\mathrm{O}_{2} \rightleftarrows \mathrm{NO}+\mathrm{OH}$ & $1.30 \cdot 10^{7}$ & 1.5 & 100 & $1.23 \cdot 10^{2}$ & 1.7 & 54616 \\
\hline 16. $N N H+O \rightleftarrows N H+N O$ & $5.00 \cdot 10^{13}$ & 0 & 0 & $3.06 \cdot 10^{13}$ & 0.36 & 12610 \\
\hline 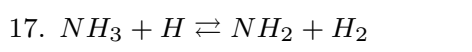 & $7.04 \cdot 10^{4}$ & 1.50 & 9048 & $1.58 \cdot 10^{5}$ & 2.0 & 3954 \\
\hline 19. $\mathrm{NH}_{3}+\mathrm{OH} \rightleftarrows \mathrm{NH}_{2}+\mathrm{H}_{2} \mathrm{O}$ & $1.19 \cdot 10^{7}$ & 2.0 & 4067 & $3.84 \cdot 10^{2}$ & 2.35 & 13924 \\
\hline 20. $\mathrm{NNH}+\mathrm{O}_{2} \rightleftarrows \mathrm{N}_{2}+\mathrm{HO}_{2}$ & $6.67 \cdot 10^{13}$ & 0 & 0 & $7.72 \cdot 10^{14}$ & 0 & 54547 \\
\hline 21. $N N H \rightleftarrows N_{2}+H$ & $1.00 \cdot 10^{7}$ & 0 & 0 & $1.00 \cdot 10^{7}$ & 0 & 0 \\
\hline 22. $\mathrm{NNH}+\mathrm{O}_{2} \rightleftarrows \mathrm{N}_{2}+\mathrm{O}_{2}+H$ & $5.00 \cdot 10^{13}$ & 0 & 0 & $9.46 \cdot 10^{6}$ & 0.35 & 6450 \\
\hline 23. $\mathrm{NO}+\mathrm{HO}_{2} \rightleftarrows \mathrm{NO}_{2}+\mathrm{OH}$ & $2.1 \cdot 10^{12}$ & 0 & 0 & $2.37 \cdot 10^{12}$ & -0.096 & 6315 \\
\hline 24. $\mathrm{NO}_{2}+\mathrm{CH}_{3} \rightleftarrows \mathrm{CH}_{3} \mathrm{O}+\mathrm{NO}$ & $1.50 \cdot 10^{13}$ & 0 & 0 & 1.97 & -0.05 & 17704 \\
\hline 25. $\mathrm{NO}_{2}+\mathrm{H} \rightleftarrows \mathrm{NO}+\mathrm{OH}$ & $1.32 \cdot 10^{14}$ & 0 & 0 & $3.13 \cdot 10^{6}$ & 0.81 & 29175 \\
\hline 26. $\mathrm{N}_{2} \mathrm{O}+\mathrm{O} \rightleftarrows 2 \mathrm{NO}$ & $6.60 \cdot 10^{13}$ & 0 & 25441 & $1.64 \cdot 10^{12}$ & 0 & 32057 \\
\hline 27. $\mathrm{CH}_{3} \mathrm{O}+\mathrm{M} \rightleftarrows \mathrm{CH}_{2} \mathrm{O}+\mathrm{H}+\mathrm{M}$ & $6.00 \cdot 10^{11}$ & 0 & 18000 & $5.68 \cdot 10^{16}$ & -2.2 & 9845 \\
\hline 28. $\mathrm{CH}_{3}+\mathrm{HO}_{2} \rightleftarrows \mathrm{CH}_{3} \mathrm{O}+\mathrm{OH}$ & $6.00 \cdot 10^{12}$ & 0 & 0 & $7.75 \cdot 10^{10}$ & -0.12 & 25380 \\
\hline 29. $\mathrm{CH}_{3}+\mathrm{O}_{2} \rightleftarrows \mathrm{CH}_{3} \mathrm{O}+\mathrm{O}$ & $4.00 \cdot 10^{12}$ & 0 & 27000 & $6.51 \cdot 10^{11}$ & -0.48 & 0 \\
\hline 30. $N H+O \rightleftarrows N O+H$ & $9.20 \cdot 10^{13}$ & 0 & 0 & $3.18 \cdot 10^{12}$ & -0.21 & 71264 \\
\hline 31. $\mathrm{NH}_{3}+\mathrm{CH}_{3} \rightleftarrows \mathrm{NH}_{2}+\mathrm{CH}_{4}$ & $7.57 \cdot 10^{1}$ & 1.84 & 10023 & $7.88 \cdot 10^{5}$ & 2 & 6420 \\
\hline
\end{tabular}

${ }^{a} k=A T^{\beta} \exp \left(-E_{a} / R T\right)$. 
Table 4: Kinetic parameters applied to $\mathrm{C} 2$ model in JHC conditions. Units: mol, cm, s, cal

\begin{tabular}{|c|c|c|c|c|c|c|}
\hline \multirow{2}{*}{ Reaction $^{a}$} & \multicolumn{3}{|c|}{ Forward } & \multicolumn{3}{|c|}{ Backward } \\
\hline & $A$ & $\beta$ & $E_{a}$ & $A$ & $\beta$ & $E_{a}$ \\
\hline 1. $N+N O \rightleftarrows N_{2}+O$ & $3.30 \cdot 10^{12}$ & 0.3 & 0 & $1.71 \cdot 10^{14}$ & 0.0 & 72887 \\
\hline 2. $\mathrm{N}+\mathrm{O}_{2} \rightleftarrows \mathrm{NO}+\mathrm{O}$ & $6.40 \cdot 10^{9}$ & 1 & 6280 & $4.92 \cdot 10^{12}$ & 0.0 & 38758 \\
\hline 3. $\mathrm{CO}_{2}+\mathrm{N} \rightleftarrows \mathrm{NO}+\mathrm{CO}$ & $1.90 \cdot 10^{11}$ & 0 & 20237 & $2.16 \cdot 10^{3}$ & 0.9 & 26372 \\
\hline 4. $N H+H \rightleftarrows N+H_{2}$ & $3.00 \cdot 10^{13}$ & 0 & 0 & $1.38 \cdot 10^{14}$ & 0.0 & 23533 \\
\hline 5. $N_{2} O+M \rightleftarrows N_{2}+O+M$ & $4.00 \cdot 10^{14}$ & 0 & 56100 & $1.067 \cdot 10^{3}$ & 1.09 & 15780 \\
\hline 6. $\mathrm{N}_{2} \mathrm{O}+\mathrm{H \rightleftarrows} \mathrm{N}_{2}+\mathrm{OH}$ & $3.30 \cdot 10^{10}$ & 0 & 4729 & $2.96 \cdot 10^{1}$ & 1.3 & 66092 \\
\hline 7. $\mathrm{N}_{2} \mathrm{O}+\mathrm{CO} \rightleftarrows \mathrm{N}_{2}+\mathrm{CO}_{2}$ & $3.20 \cdot 10^{11}$ & 0 & 20237 & $8.25 \cdot 10^{8}$ & 0.1 & 107481 \\
\hline 8. $\mathrm{N}_{2} \mathrm{O}+\mathrm{OH} \rightleftarrows \mathrm{N}_{2}+\mathrm{HO}_{2}$ & $2.37 \cdot 10^{10}$ & -0.09 & 6316 & $2.10 \cdot 10^{12}$ & 0.0 & 0 \\
\hline 9. $\mathrm{HNO}+\mathrm{H} \rightleftarrows \mathrm{H}_{2}+\mathrm{NO}$ & $8.50 \cdot 10^{11}$ & 0.5 & 655 & $7.66 \cdot 10^{6}$ & 1.2 & 54457 \\
\hline 10. $\mathrm{HCO}+\mathrm{NO} \rightleftarrows \mathrm{HNO}+\mathrm{CO}$ & $7.20 \cdot 10^{12}$ & 0 & 0 & $2.93 \cdot 10^{10}$ & 0.1 & 34525 \\
\hline 11. $H+N O+M \rightleftarrows H N O+M$ & $4.00 \cdot 10^{20}$ & -1.75 & 0 & $1.40 \cdot 10^{19}$ & -1.9 & 49824 \\
\hline 12. $\mathrm{NH}+\mathrm{O}_{2} \rightleftarrows H N O+O$ & $1.30 \cdot 10^{6}$ & 1.5 & 100 & $1.37 \cdot 10^{2}$ & 1.7 & 55902 \\
\hline 13. $\mathrm{NH}+\mathrm{NO} \rightleftarrows \mathrm{N}_{2} \mathrm{O}+\mathrm{H}$ & $2.90 \cdot 10^{14}$ & -0.4 & 0 & $6.42 \cdot 10^{17}$ & -1.5 & 35932 \\
\hline 14. $\mathrm{NH}_{2}+\mathrm{H} \rightleftarrows \mathrm{NH}+\mathrm{H}_{2}$ & $4.00 \cdot 10^{13}$ & 0 & 3650 & $5.24 \cdot 10^{9}$ & 0.2 & 15670 \\
\hline 15. $\mathrm{NH}+\mathrm{O}_{2} \rightleftarrows \mathrm{NO}+\mathrm{OH}$ & $1.30 \cdot 10^{7}$ & 1.5 & 100 & $1.23 \cdot 10^{2}$ & 1.7 & 54616 \\
\hline 16. $N N H+O \rightleftarrows N H+N O$ & $5.00 \cdot 10^{13}$ & 0 & 0 & $3.06 \cdot 10^{13}$ & 0.0 & 12610 \\
\hline 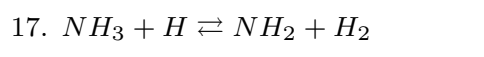 & $6.40 \cdot 10^{5}$ & 2.4 & 10171 & 1.43 & 2.9 & 5077 \\
\hline 18. $\mathrm{NH}_{3}+\mathrm{O} \rightleftarrows \mathrm{NH}_{2}+\mathrm{OH}$ & $9.40 \cdot 10^{6}$ & 1.9 & 6460 & $1.18 \cdot 10^{1}$ & 2.4 & 0 \\
\hline 19. $\mathrm{NH}_{3}+\mathrm{OH} \rightleftarrows \mathrm{NH}_{2}+\mathrm{H}_{2} \mathrm{O}$ & $2.00 \cdot 10^{6}$ & 2.1 & 566 & $5.75 \cdot 10^{1}$ & 2.4 & 10827 \\
\hline 20. $\mathrm{NNH}+\mathrm{O}_{2} \rightleftarrows \mathrm{N}_{2}+\mathrm{HO}_{2}$ & $5.00 \cdot 10^{13}$ & 0 & 0 & $7.72 \cdot 10^{14}$ & 0 & 54547 \\
\hline 21. $N N H \rightleftarrows N_{2}+H$ & $1.00 \cdot 10^{7}$ & 0 & 0 & $1.00 \cdot 10^{7}$ & 0 & 0 \\
\hline 22. $\mathrm{NNH}+\mathrm{O}_{2} \rightleftarrows \mathrm{N}_{2}+\mathrm{O}_{2}+\mathrm{H}$ & $5.00 \cdot 10^{13}$ & 0 & 0 & $9.46 \cdot 10^{6}$ & 0.35 & 6450 \\
\hline 23. $\mathrm{NO}+\mathrm{HO}_{2} \rightleftarrows \mathrm{NO}_{2}+\mathrm{OH}$ & $2.20 \cdot 10^{12}$ & 0 & 0 & $2.37 \cdot 10^{12}$ & -0.01 & 6315 \\
\hline 24. $\mathrm{NO}_{2}+\mathrm{CH}_{3} \rightleftarrows \mathrm{CH}_{3} \mathrm{O}+\mathrm{NO}$ & $1.40 \cdot 10^{13}$ & 0 & 0 & 1.97 & -0.05 & 17704 \\
\hline 25. $\mathrm{NO} 2+\mathrm{H} \rightleftarrows \mathrm{NO}+\mathrm{OH}$ & $4.00 \cdot 10^{13}$ & 0 & 0 & $2.22 \cdot 10^{6}$ & 0.81 & 28410 \\
\hline 26. $\mathrm{N}_{2} \mathrm{O}+\mathrm{O} \rightleftarrows 2 \mathrm{NO}$ & $6.60 \cdot 10^{13}$ & 0 & 25441 & $1.64 \cdot 10^{12}$ & 0 & 32057 \\
\hline 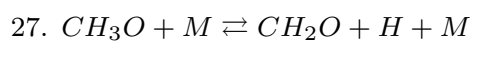 & $6.00 \cdot 10^{11}$ & 0 & 18000 & $5.68 \cdot 10^{16}$ & -2.2 & 9845 \\
\hline 28. $\mathrm{CH}_{3}+\mathrm{HO}_{2} \rightleftarrows \mathrm{CH}_{3} \mathrm{O}+\mathrm{OH}$ & $6.00 \cdot 10^{12}$ & 0 & 0 & $7.75 \cdot 10^{10}$ & -0.12 & 25380 \\
\hline 29. $\mathrm{CH}_{3}+\mathrm{O}_{2} \rightleftarrows \mathrm{CH}_{3} \mathrm{O}+\mathrm{O}$ & $4.00 \cdot 10^{12}$ & 0 & 27000 & $6.51 \cdot 10^{11}$ & -0.48 & 0 \\
\hline 30. $N H+O \rightleftarrows N O+H$ & $9.20 \cdot 10^{13}$ & 0 & 0 & $5.47 \cdot 10^{14}$ & 0 & 67482 \\
\hline
\end{tabular}

${ }^{a} k=A T^{\beta} \exp \left(-E_{a} / R T\right)$. 


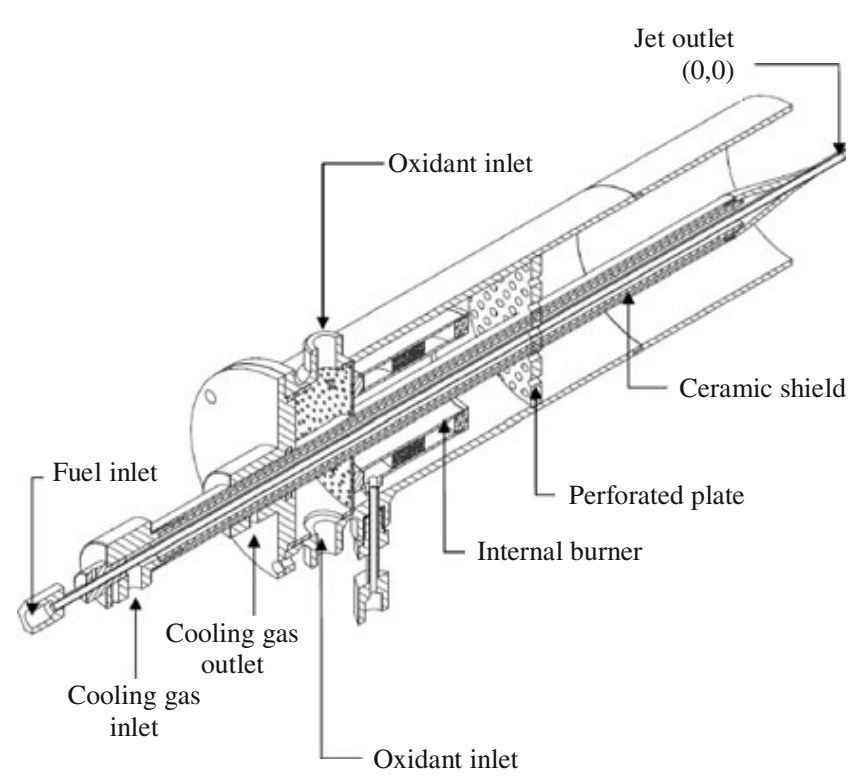

(a)

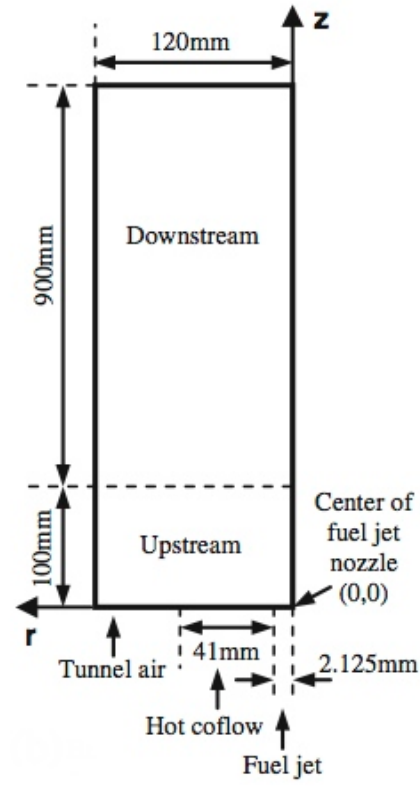

(b)

Figure 1: (a) Jet in Hot Coflow burner and (b) computational domain 


\section{Rate of Production Analysis - NO}

\begin{tabular}{|c|c|c|c|}
\hline 622 & & $\mathrm{NO}+\mathrm{HO}_{2}=\mathrm{NO} 2+\mathrm{OH}$ & -0.040 \\
\hline 694 & $\mathrm{CH} 3+\mathrm{NO} 2=\mathrm{CH} 3 \mathrm{O}+\mathrm{NO}$ & & 0.026 \\
\hline 657 & $\mathrm{NO} 2+\mathrm{H}=\mathrm{NO}+\mathrm{OH}$ & & 0.012 \\
\hline 690 & $\mathrm{NH}+\mathrm{NO}=\mathrm{N} 2 \mathrm{O}+\mathrm{H}$ & & 0.012 \\
\hline 627 & $\mathrm{HNO}+\mathrm{H}=\mathrm{NO}+\mathrm{H} 2$ & & $3.04 e-03$ \\
\hline 686 & & $\mathrm{C} 2 \mathrm{H}_{3}+\mathrm{NO}=\mathrm{C} 2 \mathrm{H} 2+\mathrm{HNO}$ & $-1.88 \mathrm{e}-03$ \\
\hline 624 & $\mathrm{NO}+\mathrm{OH}+\mathrm{M}=\mathrm{HONO}+\mathrm{M}$ & & $1.87 e_{-03}$ \\
\hline 603 & $\mathrm{NNH}+\mathrm{O}=\mathrm{NH}+\mathrm{NO}$ & & $1.65 e-03$ \\
\hline 325 & & $\mathrm{HCO}+\mathrm{NO}=\mathrm{CO}+\mathrm{HNO}$ & $-1.34 \mathrm{e}-03$ \\
\hline 326 & $\mathrm{H}+\mathrm{NO}+\mathrm{M}=\mathrm{HNO}+\mathrm{M}$ & & $1.16 \mathrm{e}-03$ \\
\hline 573 & $\mathrm{NH}+\mathrm{O}_{2}=\mathrm{NO}+\mathrm{OH}$ & & $8.75 e-04$ \\
\hline 580 & $\mathrm{~N}+\mathrm{NO}=\mathrm{O}+\mathrm{N} 2$ & & \\
\hline 579 & $\mathrm{~N}+\mathrm{O} 2=\mathrm{NO}+\mathrm{O}$ & & $7.120-04$ \\
\hline 596 & $\mathrm{NO}+\mathrm{CH} 4=\mathrm{HNO}+\mathrm{CH} 3$ & & $1.61 \mathrm{e}-04$ \\
\hline 681 & $\mathrm{CO} 2+\mathrm{N}=\mathrm{NO}+\mathrm{CO}$ & & $1.36 e-04$ \\
\hline 691 & $\mathrm{~N} 2 \mathrm{O}+\mathrm{O}=2 \mathrm{NO}$ & & $1.16 \mathrm{e}-04$ \\
\hline 630 & $\mathrm{HNO}+\mathrm{O}_{2}=\mathrm{NO}+\mathrm{HO} 2$ & & $9.15 \mathrm{e}-05$ \\
\hline 664 & $\mathrm{CO}+\mathrm{NO} 2=\mathrm{CO} 2+\mathrm{NO}$ & & \\
\hline 629 & $\mathrm{HNO}+\mathrm{OH}=\mathrm{NO}+\mathrm{H} 2 \mathrm{O}$ & & $6.51 \mathrm{e}-05$ \\
\hline & & $\mathrm{CH} 2+\mathrm{NO}=\mathrm{NCO}+\mathrm{H}_{2}$ & \\
\hline
\end{tabular}

(a)

Rate of Production Analysis - NO

\begin{tabular}{|c|c|c|c|}
\hline 242 & & $\mathrm{HO} 2+\mathrm{NO}=\mathrm{NO} 2+\mathrm{OH}$ & -0.027 \\
\hline 342 & $\mathrm{CH} 3+\mathrm{NO} 2=\mathrm{CH} 3 \mathrm{O}+\mathrm{NO}$ & & 0.020 \\
\hline 298 & $\mathrm{NH}+\mathrm{NO}=\mathrm{N} 2 \mathrm{O}+\mathrm{H}$ & & 0.016 \\
\hline 243 & $\mathrm{NO} 2+\mathrm{H}=\mathrm{NO}+\mathrm{OH}$ & & $7.020-03$ \\
\hline 299 & & $\mathrm{NH}+\mathrm{NO}=\mathrm{N} 2 \mathrm{O}+\mathrm{H}$ & $-4.21 \mathrm{e}-03$ \\
\hline 253 & $\mathrm{HNO}+\mathrm{H}=\mathrm{H} 2+\mathrm{NO}$ & & $2.03 e-03$ \\
\hline 338 & & $\mathrm{HCO}+\mathrm{NO}=\mathrm{HNO}+\mathrm{CO}$ & $-1.38 \mathrm{e}-03$ \\
\hline 347 & & $\mathrm{C} 2 \mathrm{H}_{3}+\mathrm{NO}=\mathrm{C} 2 \mathrm{H} 2+\mathrm{HNO}$ & $-1.21 \mathrm{e}-03$ \\
\hline 319 & $\mathrm{NNH}+\mathrm{O}=\mathrm{NH}+\mathrm{NO}$ & & $1.13 \mathrm{e}-03$ \\
\hline 238 & $\mathrm{H}+\mathrm{NO}+\mathrm{M}=\mathrm{HNO}+\mathrm{M}$ & & $1.01 \mathrm{e}-03$ \\
\hline 306 & $\mathrm{~N}+\mathrm{NO}=\mathrm{N} 2+\mathrm{O}$ & & $8.57 e-04$ \\
\hline 305 & $\mathrm{~N}+\mathrm{O} 2=\mathrm{NO}+\mathrm{O}$ & & $7.17 \mathrm{e}-04$ \\
\hline 297 & $\mathrm{NH}+\mathrm{O}_{2}=\mathrm{NO}+\mathrm{OH}$ & & $6.900-04$ \\
\hline 239 & $\mathrm{H}+\mathrm{NO}+\mathrm{N} 2=\mathrm{HNO}+\mathrm{N} 2$ & & $3.62 \theta-04$ \\
\hline 336 & $\mathrm{CO} 2+\mathrm{N}=\mathrm{NO}+\mathrm{CO}$ & & $1.65 e-04$ \\
\hline 241 & $\mathrm{OH}+\mathrm{NO}+\mathrm{M}=\mathrm{HONO}+\mathrm{M}$ & & $9.07 \mathrm{e}-05$ \\
\hline 334 & $\mathrm{CO}+\mathrm{NO} 2=\mathrm{CO} 2+\mathrm{NO}$ & & $7.52 e-05$ \\
\hline 329 & $\mathrm{~N} 2 \mathrm{O}+\mathrm{O}=2 \mathrm{NO}$ & & $6.46 e-05$ \\
\hline 256 & $\mathrm{HNO}+\mathrm{O} 2=\mathrm{HO} 2+\mathrm{NO}$ & & $4.97 \mathrm{e}-05$ \\
\hline 255 & $\mathrm{HNO}+\mathrm{OH}=\mathrm{NO}+\mathrm{H} 2 \mathrm{O}$ & & $4.120-05$ \\
\hline
\end{tabular}

Figure 2: NO Rate Of Production Analysis (ROPA) for (a) C1 and (b) C2 models. Blue lines indicate NO destruction, while the red ones NO formation. 

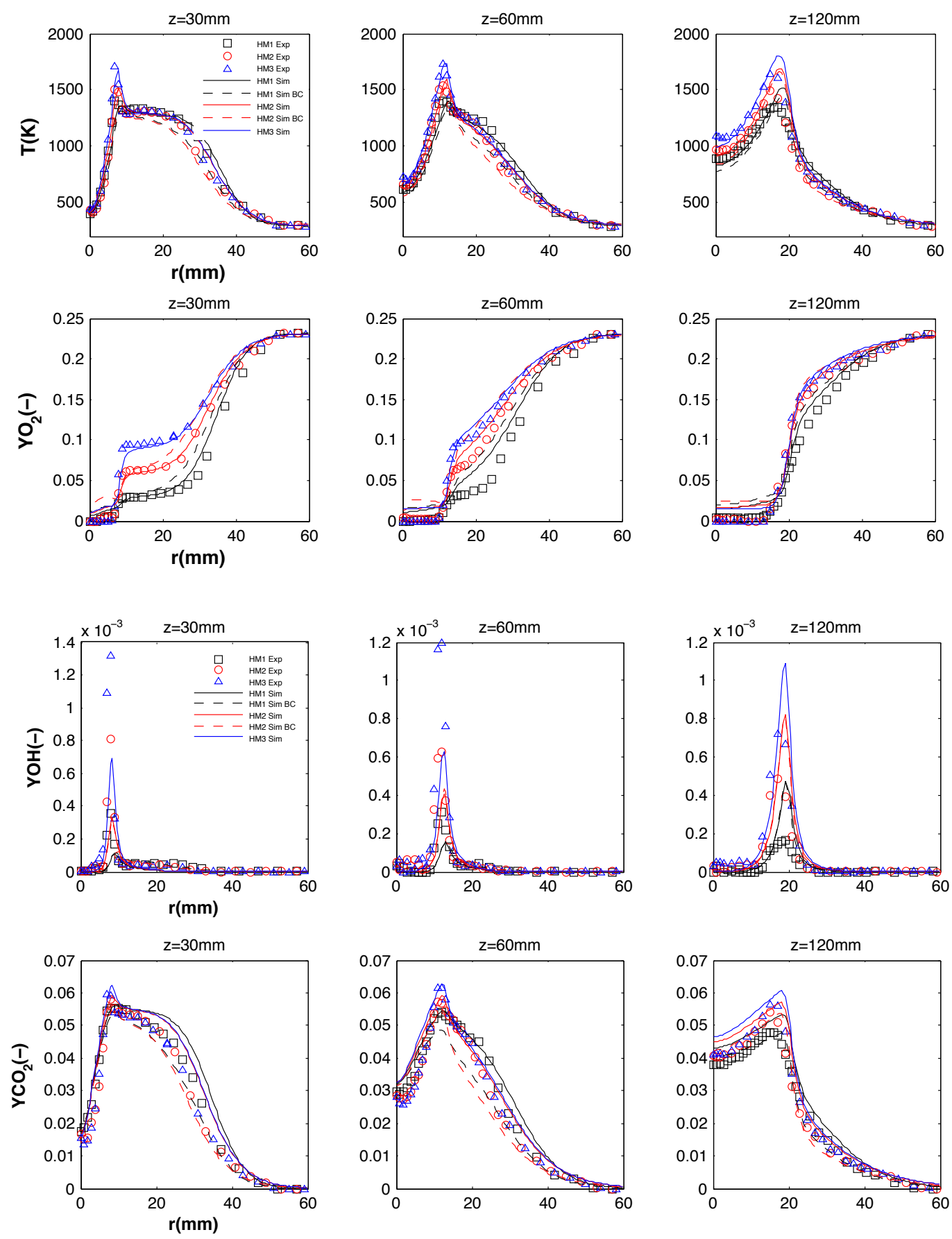

Figure 3: Comparison between measured and predicted radial profiles of temperature, $\mathrm{O}_{2}, \mathrm{OH}$ and $\mathrm{CO}_{2}$ at different axial locations for HM1, HM2 and HM3 flames. 

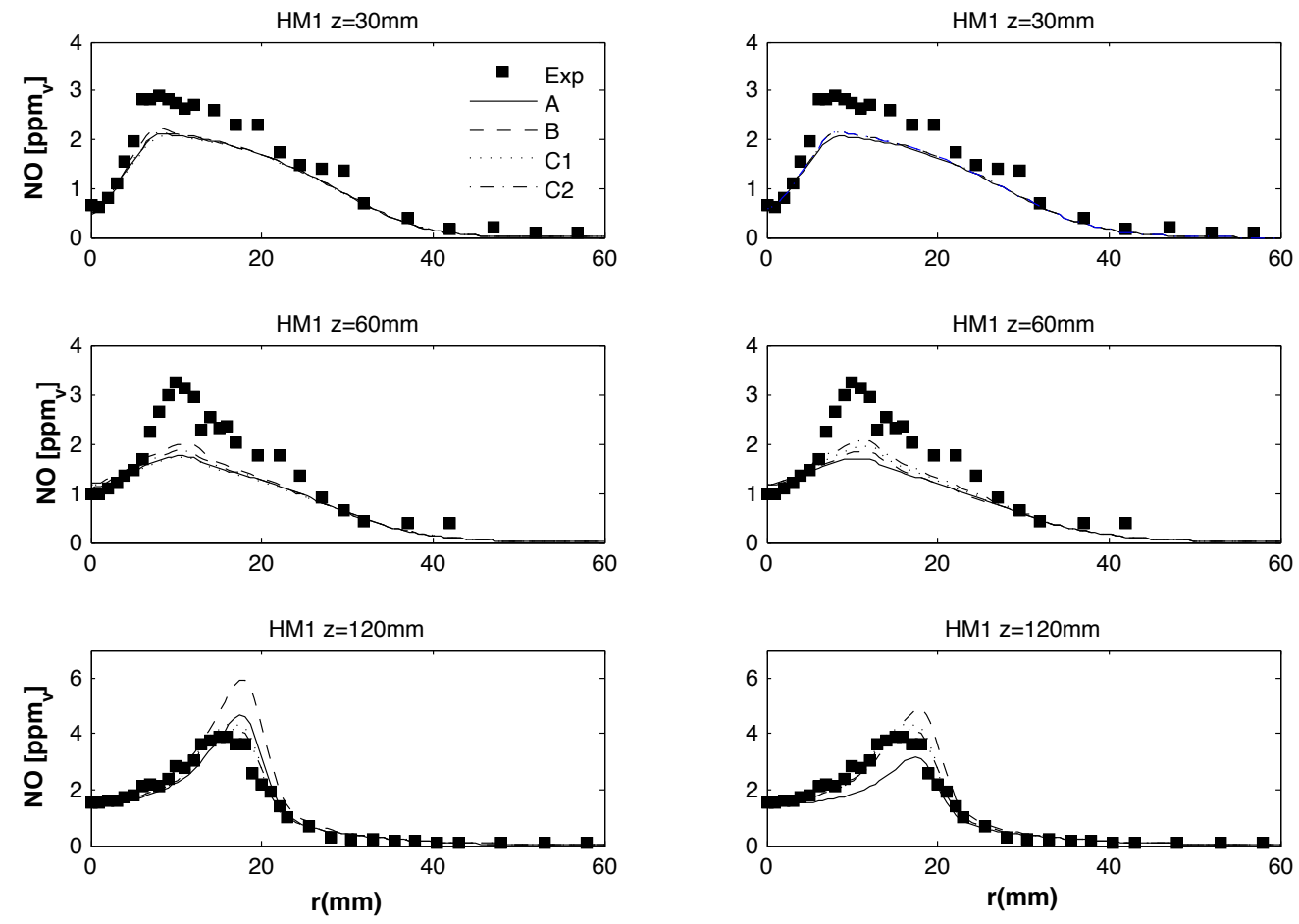

Figure 4: Comparison between measured and predicted radial profiles of NO obtained using constant (on the l.h.s.) and experimental profile (r.h.s.) boundary conditions for flame HM1. 

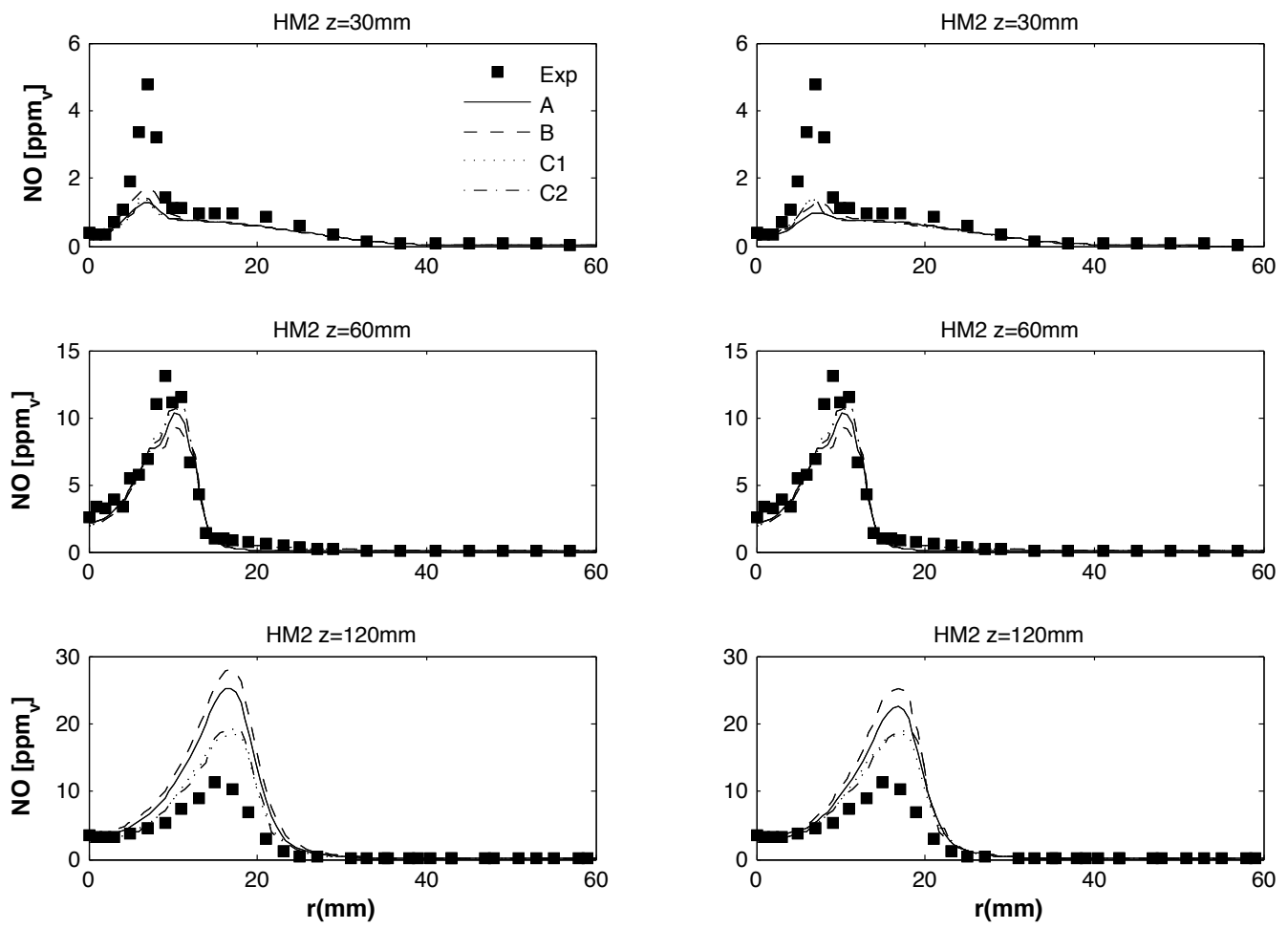

Figure 5: Comparison between measured and predicted radial profiles of NO obtained using constant (on the 1.h.s.) and experimental profile (r.h.s.) boundary conditions for flame HM2. 

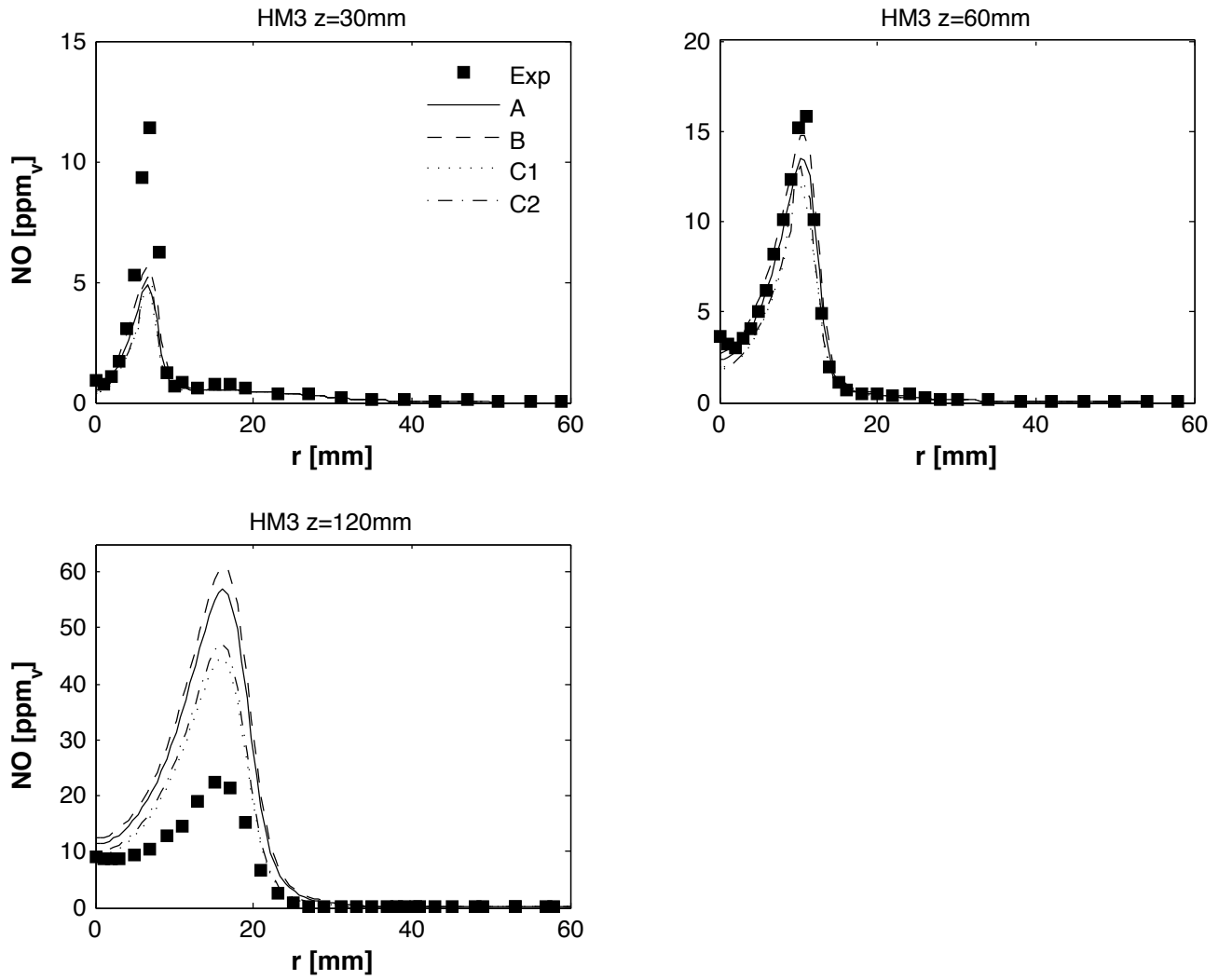

Figure 6: Comparison between measured and predicted radial profiles of NO for flame HM3. 


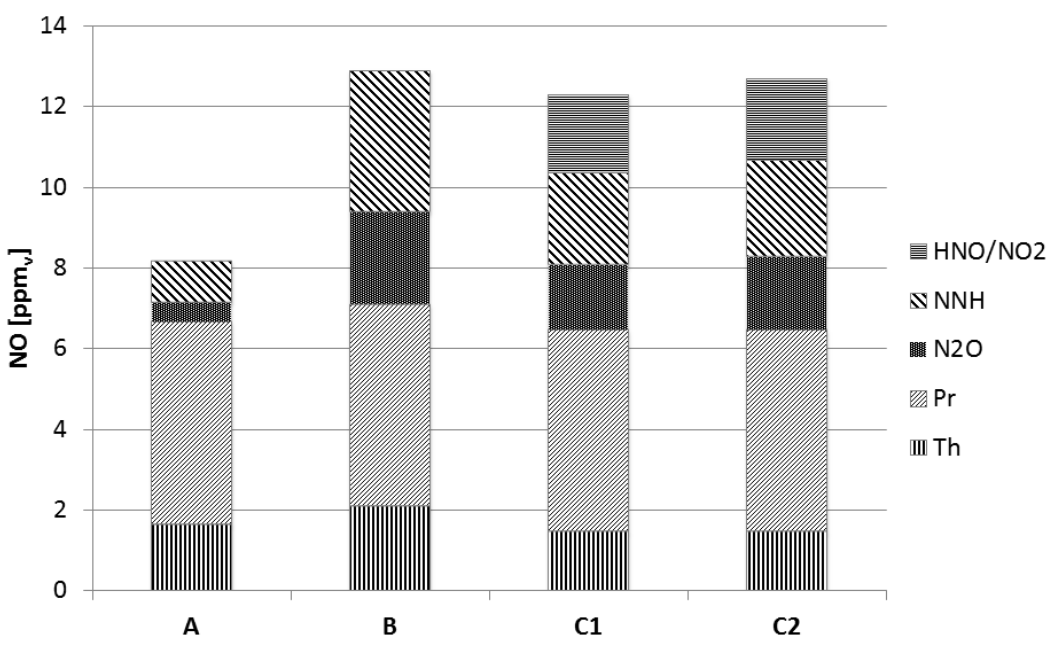

(a)

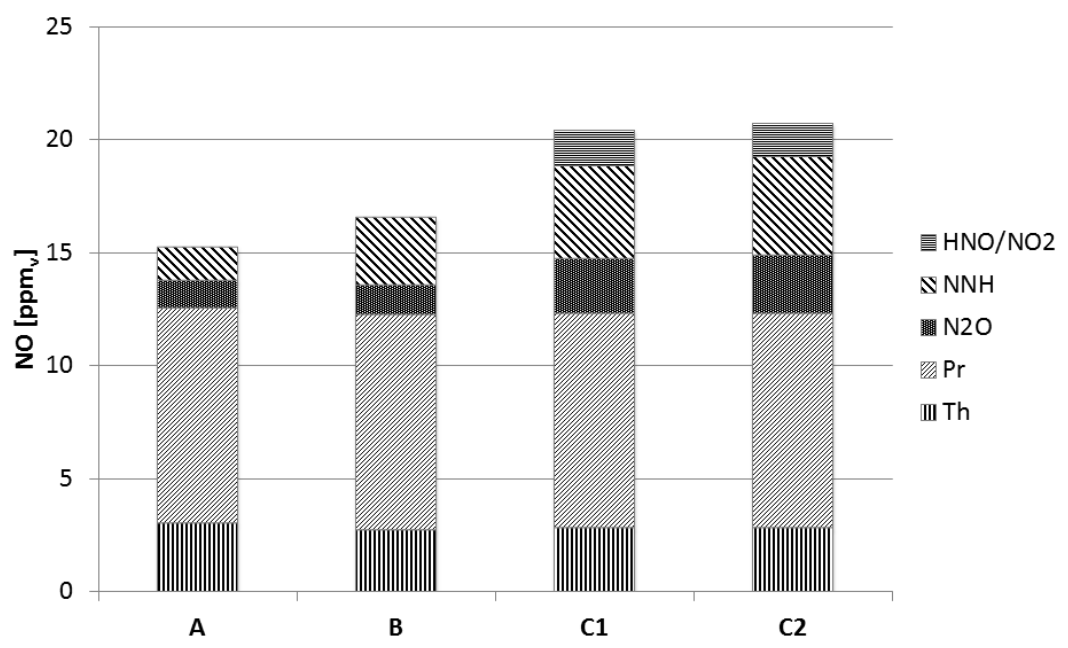

(b)

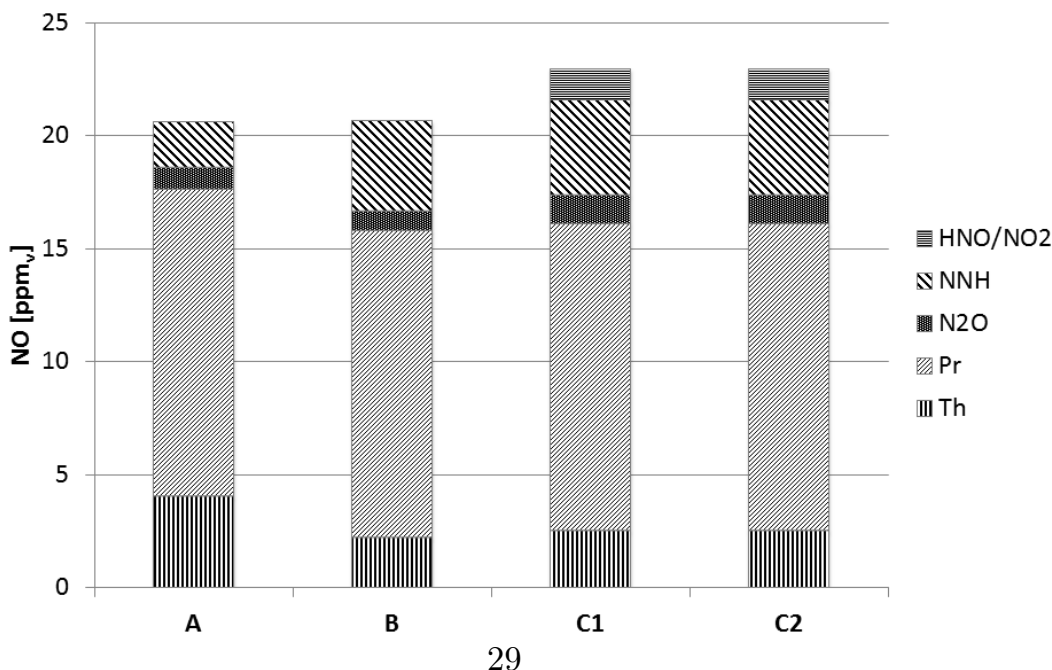

Figure 7: Relative importance of NO formation routes for flame (a) HM1, (b) HM2; (c) HM3 at the outlet section as calculated with the different models, i.e. A, B, C1 and C2 

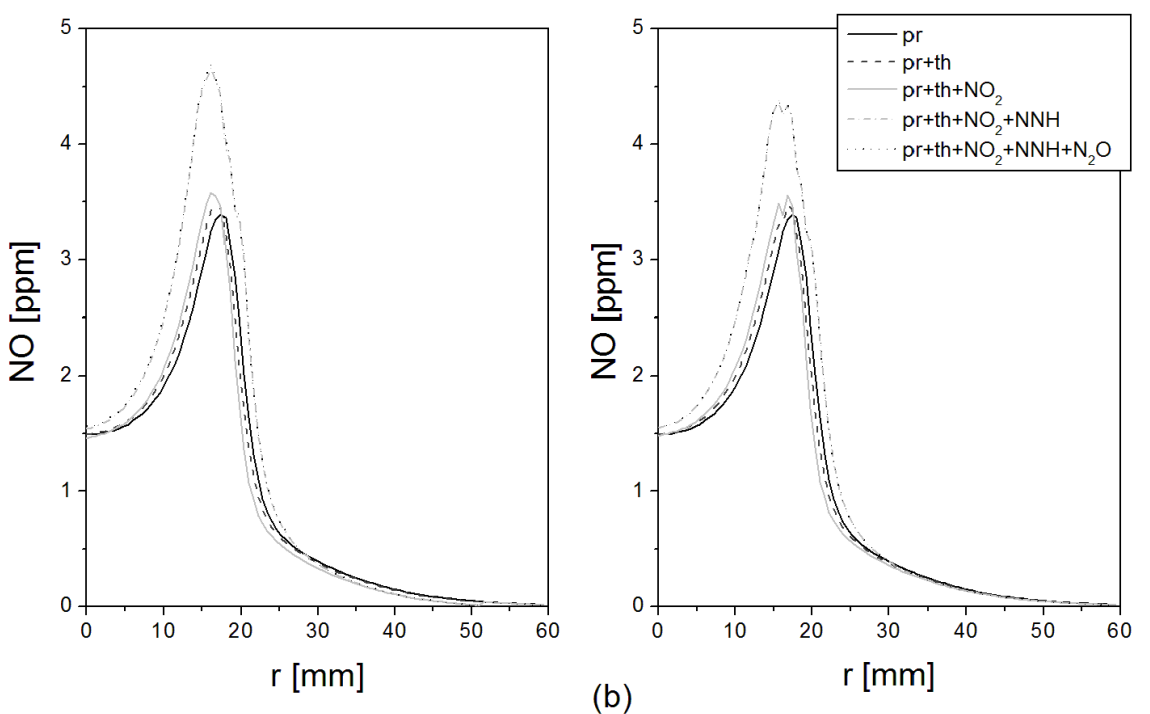

(a)

(b)

Figure 8: Contribution of the different routes to radial profile of NO emissions at $z=120 \mathrm{~mm}$ for HM1 flame predicted with (a) $\mathrm{C} 1$ model and (b) $\mathrm{C} 2$ model. 


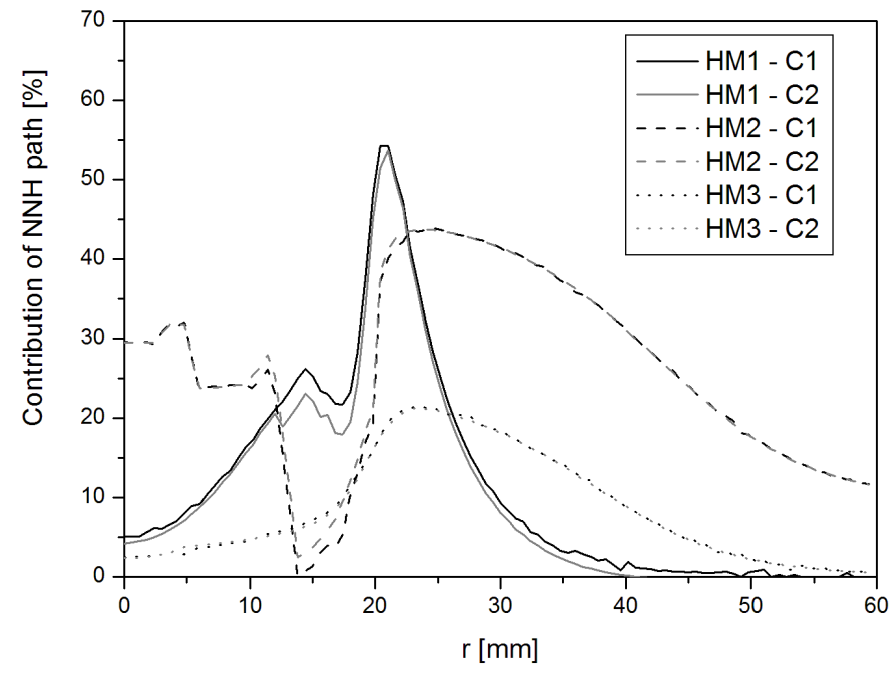

Figure 9: Radial profile of the contribution of NNH path to the total NO emissions at $z=120 \mathrm{~mm}$ for the three flames as predicted with $\mathrm{C} 1$ and $\mathrm{C} 2$ models. 